\title{
Sustainability vs. Quality in gilthead seabream (Sparus aurata L.) farming: are trade-offs inevitable?
}

\author{
Elisabete Matos ${ }^{1}$, Jorge Dias², Maria T. Dinis ${ }^{3}$ and Tomé S. Silva ${ }^{2}$ \\ 1 Sorgal - Sociedade de Óleos e Rações, S.A., Lugar da Pardala, S. João de Ovar, Portugal \\ 2 SPAROS Lda., Área Empresarial de Marim, Olhão, Portugal \\ 3 CCMAR, Centro de Ciências do Mar do Algarve, Universidade do Algarve, Faro, Portugal
}

\section{Correspondence}

Elisabete Matos, Sorgal - Sociedade de Óleos e

Rações, S.A., 3880-278 S. João de Ovar,

Portugal. Email: elisabete.dm@gmail.com

Received 21 August 2015; accepted 17 January 2016.

\begin{abstract}
European aquaculture industry should be at the forefront of sustainable development, providing healthy and safe food of the highest quality to the consumer, through an environmentally sound approach. The purpose of this review was to explore in what way the current drive for sustainability has affected what the consumer perceives as quality in fish, specifically in gilthead seabream, one of the most important farmed species in the Mediterranean. It focuses on nutritional aspects such as fish meal and fish oil replacement, quality tailoring through finishing strategies, the influence of different farming systems and the effect of slaughter stress on seabream quality. In general, fish meal and fish oil replacement with vegetable ingredients will result in changes in the fatty acid profile of the fillets, and consequently the potential health benefits seabream offers to the consumer. While organoleptic properties suffer little change, the impact of these ingredients on welfare has not been fully investigated. Further studies are also needed to evaluate the effect of land animal ingredients on seabream quality. In either case, although finishing strategies to restore essential fatty acids are not completely effective, seabream can still retain a high nutritional value. Information on the use of dietary supplements as finishing strategies is still extremely scarce. Regarding fish welfare, the high densities practised in intensive production systems pose concerns which warrant further research in this area. Furthermore, new alternatives for common harvesting and slaughter methods are needed to improve welfare, as traditional methods are clearly stressful.
\end{abstract}

Key words: animal by-products, fish quality, gilthead seabream, sustainability, vegetable ingredients.

\section{Introduction}

The world population continues to growth exponentially, and the current growth cannot be sustained without a concomitant growth in the food supply. Total captures from fisheries have plateaued in the 1990s at around 90 million tonnes per year (FAO 2014). Nonetheless, the per capita consumption of fishery and aquaculture products has been growing in parallel with the world population growth, and this increase is due solely to the increase in aquaculture production in the past decades, that went from 32.4 million tonnes in the year 2000 to around 66.6 in 2012, excluding aquatic plants (FAO 2014). In 2012, around 69\% of the global farmed aquatic animal production was feed-dependent, either of farm-made or industrial-made aquafeeds (FAO 2014).

Considering that (traditionally) industrial fish feeds for aquaculture are produced from marine ingredients mainly fish meal and fish oil from targeted fisheries of small pelagic fish without commercial value for direct human consumption - concerns that we are merely trading one issue (decline in high-value fisheries stocks) for another have arisen (Naylor et al. 2000). Additionally, reduction fisheries for the production of fish meal and fish oil could be used to feed people rather than farmed fish, as the demand for small pelagic fish for direct human consumption is likely to increase with the population growth (Naylor et al. 2000). Furthermore, because dedicated 
fisheries are now being monitored and well managed, and quotas have been set, the production of fish meal and fish oil is expected to remain the same or decrease slightly in the coming years, and consequently will not be able to support current market needs (Jackson 2012). Having this problem in mind, research has been conducted in the past two decades with the express purpose of alleviating the need for marine ingredients in fish feeds, as well as improving the efficiency of the aquaculture production, through the development of efficient farming practices (such as feeding practices, technical improvements in production systems and rearing conditions). One general vision shared by all stakeholders is that the European aquaculture industry of the future should be at the forefront of sustainable development, providing healthy and safe food of the highest quality to the consumer, through an environmentally sound approach.

The question that arises from the changes we, as researchers and producers, are investigating and implementing in the aquaculture world, is whether - and if so, in what way - these new and improved practices affect what we, as consumers, perceive to be the quality of the final product: the fish.

There is ample evidence that some quality criteria can be affected by the fish's life history. A considerable amount of research has been carried out in several fish species, outlining overall quality differences between, for example, cultured and wild fish of the same species (e.g. Grigorakis 2007), fish originating from different production systems and/or levels of intensity (e.g. Flos et al. 2002), or fish subjected to farming practices capable of inducing diverse levels of stress (e.g. Poli et al. 2005). Additionally, it is generally recognized that, within some limits, the nutritional profile of the fish (and consequently, one of the benefits for the consumer) is affected by that of the diets used (e.g.
Izquierdo et al. 2005). So, the question of whether the different farming practices, as a whole, have the potential to alter what the consumer perceives as quality has already been answered: yes.

The purpose of this review is to discuss in what way the current drive for sustainability, with the changes it has brought about (or will bring) in the aquaculture sector, has affected what the consumer perceives as quality in fish, specifically in gilthead seabream.

\section{Current sustainability trends in aquaculture}

The concept of sustainable development as we know it was mostly established with the publication of the Brundtland Report, 'Our Common Future' (Brundtland 1987). Although it does not unambiguously define it, this document states that a sustainable development relies on an adequate management of the resources and systems that support human life, having into account both short- and long-term processes/impacts/risks ('meet the needs of the present without compromising the ability of future generations to meet their own needs'). Besides this definition, the Brundtland Report also defined the pillars on which sustainable development must stand: economy, environment, society. Although this definition is generally agreed upon, it is broad to the point of vagueness and, as such, subjected to different interpretations (Adams 2006). Furthermore, it is often difficult to reach a consensus on implementation details regarding most issues, due to the subjective nature of the relative importance of the different aspects and trade-offs required for a sustainable development. Nevertheless, one cannot deny that the pursuit of sustainability is presently a major drive in all areas of development, and the aquaculture sector (from feed producers, to fish farmers, to retail) is not an exception (Fig. 1). It is not our purpose to

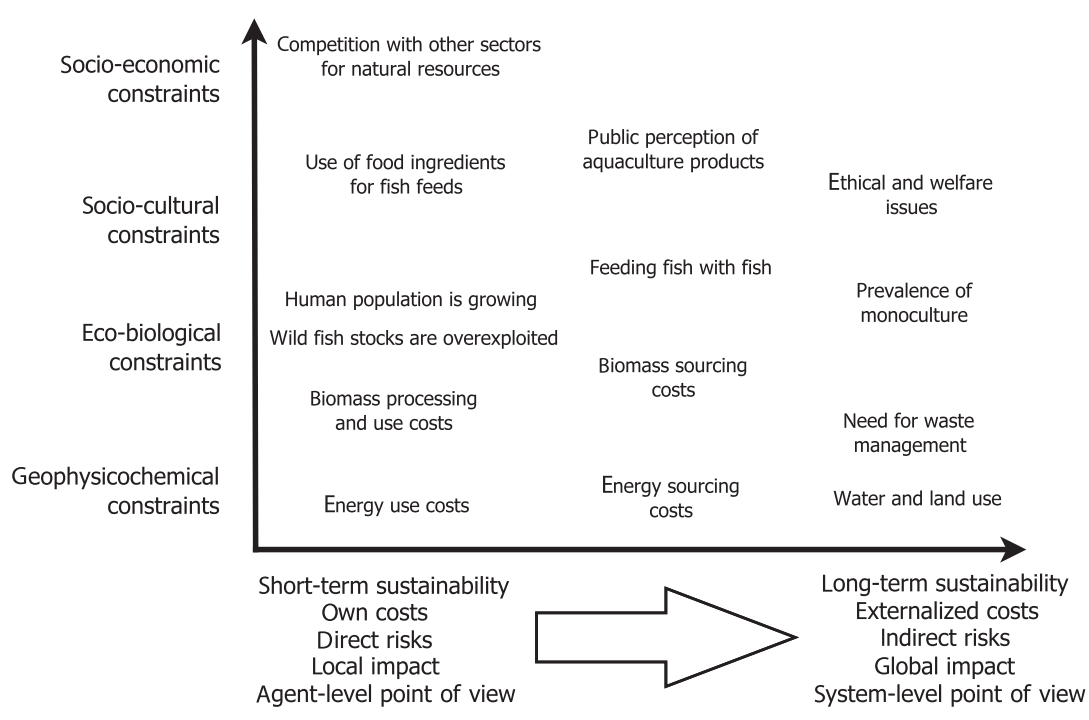

Figure 1 Diagram detailing some of the main sustainability issues that concern the aquaculture sector stakeholders. The vertical axis indicates the hierarchical level of the constraints from which the issues result, while the horizontal axis mostly indicates the (temporal/ spatial) scale of the risk/impact. In this diagram, 'economic issues' are mostly on the left side, 'environmental issues' are mostly on the right side and 'social issues' are mostly on the top. 
evaluate whether or not the raised issues and proposed changes in the aquaculture sector attributed to sustainability trends are true to the definition of sustainability, but to identify those issues/changes within each of the pillars of sustainable development.

\section{Economical}

The costs associated with fish farming vary greatly between farming systems. Traditional systems of extensive farming have small production outputs (typically less than $1 \mathrm{~kg} \mathrm{~m}^{-3}$, Morales 1991) and usually do not require industrial feeds, as the environment is able to provide all the necessary nourishment. Extensive farming in earth ponds is habitually carried out as a complementary source of income for families (Naylor et al. 2000). If we consider intensive farming, the costs associated with industrially manufactured compound aquafeeds will typically exceed $50 \%$ of the total production costs (Volpato et al. 2007). As such, one of the current research trends is the replacement of high-priced ingredients such as fish meal and fish oil with lower cost ingredients, to lower the cost of aquafeeds. This replacement has been done mainly through the use of vegetable ingredients (with soya bean being one of the most used), but also using by-products of the poultry and meat industries (Anastasiou \& Nengas 2005). Besides lowering the price of aquafeeds, it is also important to improve feed efficiency, by lowering feed conversion ratios - and consequently achieving higher productivity with a lower amount of feed.

One of the most recent trends in intensive aquaculture production is the development of added-value products that can ensure the economic sustainability of the sector. Although in the Mediterranean area fish are typically sold whole, nowadays one can buy, for example, ready-packed fillets of sea bass and seabream, and methods to increase the shelf life of this type of product are being developed (Gonçalves et al. 2004). When discussing the benefits of ready-packed seafood products, one must take into account that most packages used are fossil fuel-based, and this type of presentation represents an environmental sustainability challenge. Instead, we should consider from the onset the use of eco-friendly packaging, such as biopolymers (e.g. polyhydroxybutyrate) - although these products are by no means environmentally 'perfect' and further research is necessary, they represent a step in the right direction (Álvarez-Chávez et al. 2012). Another major trend in research is the development of tailor-made seafood (such as functional foods with, for instance, health benefits such as optimal omega-3 levels and enrichment with micronutrients such as selenium), as can be seen from the investment made by the EU in projects like SEAFOODplus (www.seafoodplus.org) and positive scientific opinions voiced by the European Food Safety Authority on the benefits of omega-3 consumption (EFSA 2010).

Besides lowering aquafeed prices, increasing efficiency and developing added-value aquaculture products, the economic sustainability of the sector depends on the diversification of farmed species. Currently, the major farmed species in Europe are Atlantic salmon (Salmo salar L.), rainbow trout (Oncorhynchus mykiss Walbaum), gilthead seabream, European sea bass (Dicentrarchus labrax L.) and common carp (Cyprinus carpio L.), with seabream and sea bass being the two most farmed species in the Mediterranean area (European Commission 2012). Species traditionally farmed in Europe are carnivorous species, which require high levels of good-quality protein. Not only is it necessary to shift to less nutritionally demanding species, such as Nile tilapia (Oreochromis niloticus L.), due to the current constraints in aquafeed ingredients, but it is also important to further develop farming of high-value species such as Senegalese sole (Solea senegalensis Kaup), in order to improve profit margins.

\section{Environmental}

The replacement of fish meal and fish oil in aquafeeds poses other sustainability issues besides economical ones. These ingredients originate primarily from directed captures of low-value fish species such as Peruvian anchoveta (Engraulis ringens Jenyns) and menhaden (Brevoortia tyrannus Latrobe), and the largest part of fish meal and fish oil production comes from South America (FAO 2011). Not only is it not considered environmentally sustainable to feed farmed fish with wild caught fish, but we have to consider also the carbon footprint involved in importing ingredients from South America to manufacture aquafeeds in Europe. Even if we consider that the species used to produce these ingredients are irrelevant from a human consumption perspective, these small pelagic fish are very important for the trophic chain, and the effects these fisheries have on the ecosystem must not be overlooked. From an environmental point of view, the use of vegetable ingredients poses similar problems, as the main markets for soya bean meal (and other typical vegetable ingredients in aquafeeds) are American. Additional concerns with the use of vegetable ingredients in aquafeeds, from an environmental point of view, are the use of land (deforestation), the use of chemicals (mainly pesticides) and the use of copious amounts of water during its production. Other authorized alternative feed resources are processed animal proteins (PAPs), which are ingredients derived only from by-products of animals which are fit for human consumption (Category 3 under the European classification). PAPs are available in considerable quantities in the EU market, and their use can reduce the dependency 
on third-country supplies and counterbalance the $-70 \%$ protein deficit that currently characterizes the EU animal feed sector. There are, however, few studies focusing on the sustainability of such ingredients.

The use of industrial aquafeeds can lead to high loads of nitrogen and phosphorus in the discarded water from fish farms (Focardi et al. 2005). Excreted nitrogen results mainly from inefficiency in protein retention, either from providing excess protein in the diets or from the inadequacy of the protein source. Some ingredients used in aquafeeds have imbalanced amino acid profiles, which will lead to poorer nitrogen retention (and consequently higher excretion). Phosphorus digestibility in the diets can vary greatly depending on the source. Vegetable ingredients will typically have less digestible phosphorus, as the main form present is phytate, which is mostly unavailable to fish.

It is also important to take into account the different environmental impacts posed by the distinct types of production systems. The more intensive the system, the higher the load of organic matter released into the environment will be. Although well-managed earth ponds (with low densities and tidal water renewal) are environmentally friendly in nature, if the feed management in the farm is poor, the load of pollutants released will increase. Sea cages are usually very intensive, releasing high loads of organic matter, and require boat use for normal operations, increasing the carbon footprint of the final product. Intensive recirculating systems, if well designed, can be very effective from an environmental perspective, but only if no water heating is necessary or the energy used is renewable. The effluents must be treated, but otherwise, these are usually very controlled systems where the feed conversion ratios are lower than what we see in other farming systems, and this efficiency is a plus.

An eco-friendly diet must have nutrient levels reduced to the minimum requirements of the fish species and be made of highly digestible ingredients (which can be processed to increase digestibility) to reduce nutrient output into the system. Current trends in aquafeed development include supplementation with synthetic amino acids to improve the amino acid balance and allow for lower protein levels in the diets, thus reducing nitrogen loads in the environment, and the use of digestibility enhancers (such as phytases) in the diets to increase phosphorus availability and overall performance. The use of locally produced ingredients and by-products of other industries is also considered a major step towards environmental sustainability.

A growing trend in aquaculture is organic farming. The Council Regulation (EC) No 834/2007 (European Union 2007) defines organic production as 'an overall system of farm management and food production that combines best environmental practices, a high level of biodiversity, the preservation of natural resources, the application of high animal welfare standards and a production method in line with the preference of certain consumers for products produced using natural substances and processes'. It is a holistic approach to farming that encloses the full production cycle and, even though the main perceived benefits are environmental, organic farming is a good example of the interaction between the three main axes of sustainability. From an economical perspective, organic products cater to an added-value market, responding to a consumer demand. However, such economic benefits must be evaluated together with the premium price that is placed on organic feeds and fry, and added production costs resulting from the lower stocking densities used. From an environmental perspective, organic farming delivers public goods contributing to the protection of the environment, with production methods aiming to be as close to nature as possible. From a societal perspective, organic farming strives to improve animal welfare, as well as rural development (European Union 2007). Most private organic standards go beyond EU legislation, including social requirements as well as addressing employment situation and the conduct of stakeholders. According to Eurostat (2015), in 2014, total production of organic aquaculture in Europe, including aquatic plants, was around 63 thousand tons, representing a more than $20 \%$ increase over 2013 production. The data per species are not fully available, and, in the case of gilthead seabream, only $150 \mathrm{~kg}$ produced in Spain was reported (data for other countries is not available for this species). In Norway, for example, 16 thousand tons of organic aquaculture products are reported, and we could easily assume these correspond almost totally to salmon farming. However, reported organic salmon in Europe is only around 45 tons (in Romania) and data per species for Norway are unavailable. So, while it is difficult to understand whether there is capacity for growth in Mediterranean fish organic farming, it is undeniable that organic production has been increasing in the last few years, since the 2014 European production is already higher than the 2008 Global production of 53.5 thousand tons, 25 of which produced in Europe (Prein et al. 2012). Mente et al. (2011) published a relevant review focusing on nutrition in organic aquaculture. Although there has been an increase in organic production in the last few years, the authors point out that organic aquaculture is still in its infancy, mainly due to the variety of cultured species and production methods, which results in difficulty to adapt to organic practices. Additionally, until recently there was a lack of universally accepted standards and accreditation criteria. The authors also suggest further research is needed to evaluate the effects of organic feed ingredients on final product quality. 


\section{Social}

Economic and environmental interests are fairly easy to identify, whereas social sustainability can be less clear. Is it sustainable to use in aquafeeds ingredients that can be used for direct human consumption? The same problem applies to the use of vegetable ingredients in aquafeeds. Social sustainability encompasses subjects such as ensuring proper welfare management, food quality and security (absence of contaminants such as antibiotics and heavy metals, freshness and microbiological safety, non-GMO products) and also product convenience (packaging, pre-prepared foods). The perception of concepts such as 'fish in-fish out' ratios is increasing among the consumers, resulting in yet another pressure point on the use of marine ingredients in aquafeeds.

One aspect often overlooked is the socio-economic and patrimonial value of aquaculture systems. Nonintensive farming systems play a key role in maintaining ecosystems functionalities and services supported by the ecosystems in confined and intertidal areas. For instance, traditional fish ponds in coastal wetlands in the French Atlantic and Spanish South Atlantic Coasts are still colonized by the natural entry of eels and play a relevant role in maintaining the eel life cycle and the fishery of this species. A patrimonial audit conducted within the framework of the EU project SEACASE 'Sustainable extensive and semi-intensive coastal aquaculture in Southern Europe' showed that in the long run it will be less costly to maintain low-technology systems than wetlands with previous human intervention abandoned. Noneconomic profits should be included when economic viability of these systems is evaluated. Additionally, in 2012 the European aquaculture was responsible for 80000 jobs in the sector. According to the European Commission, if aquaculture could increase productivity by one per cent to meet the rise in consumption and to reduce the deficit in production compared to imports, it would increase the number of jobs connected to the sector by between 3000 and 4000 .

Most of the issues that can impact social sustainability intertwine with environmental and economic sustainability, and it is of paramount importance that we are able to guarantee such social demands without compromising the other sustainability axes, that is to say, we need to have a global view of what sustainability in aquaculture is and how to reach it to the best of our abilities.

\section{The concept and importance of quality in fish}

Fish quality is an important aspect of aquaculture production and research, which pertains to the value-determining attributes of fish products and consumers' expectations regarding these attributes (Fig. 2). Although there are many different formulations of this concept, it is commonly agreed that sought-for qualities can be generally categorized as either search qualities (i.e. attributes that can be directly perceived before purchase), experience qualities (i.e. attributes that can only be perceived after purchase, when consuming the product) or credence qualities (i.e. attributes that are valued by the consumer, but are not readily perceived without explicit clues).

In the field of Food Science, the concept of 'fish quality' usually refers specifically to the assessment of the organoleptic properties of fish products (both through sensory and instrumental approaches), as well as to the study of the impact of different factors on these organoleptic properties, thus putting emphasis on the search and experience quality aspects of fish products. Nevertheless, a complete understanding of the relation between fish product attributes and perceived value to the consumer cannot simply rely on these aspects, as fish products are sold as an added-value product, rather than a commodity. There are
Figure 2 Representation of the main factors affecting the quality of aquaculture products, both at the product value and at the consumer perception level.

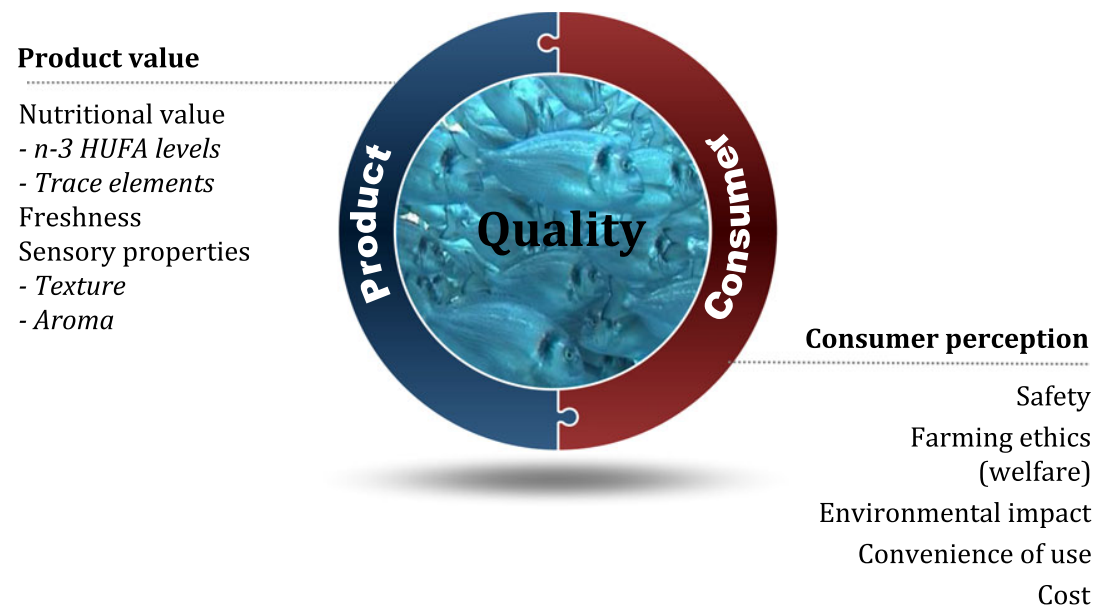

Reviews in Aquaculture (2016) 0, 1-22

(c) 2016 Wiley Publishing Asia Pty Ltd 
clearly many aspects of fish quality that, although valued by the consumer, are not immediately apparent (i.e. credence attributes): besides the quality aspects that are common to most food products, such as nutritional value (e.g. Amerio et al. 1996), food safety and product stability (e.g. Ashie et al. 1996; Matos et al. 2011; Focardi et al. 2005; Reilly \& Käferstein 1997), the consumer of fish products is often concerned about issues related to farming ethics and environmental impact, namely in terms of the use of sustainable farming practices which take into account animal welfare. As such, the issues underlying food traceability and certification (e.g. Moretti et al. 2003) are very relevant in this context to help the consumer accurately assess product value.

Although all these aspects are essential to determine the product's ultimate quality and value (Verbeke et al. 2005), from the consumer's point of view, this section focuses mostly on the organoleptic attributes of fish products, which are a central topic in aquaculture research, as these are readily assessed in a more objective way and are essential as intrinsic quality cues for the consumer. Although, in general terms, consumers tend to expect organoleptic attributes of cultured fish to be as close as possible to wild fish, the typical (i.e. in the wild) values of the different attributes (along with their respective weight in the determination of fish quality) are very much species-dependent (and sometimes even population-dependent). Furthermore, it is important to take into account that consumers' expectations are inherently subjective and even prone to change over time, which implies that it might not always be possible to define universally optimal organoleptic attributes, even within a particular species.

Given that the edible part of fish is usually the fillet, which is mostly composed by skeletal muscle (along with variable amounts of connective and adipose tissue), factors such as muscle cellularity, composition and macrostructure are highly determining of the products' ultimate quality. Within this context, the assessment of fish meat quality appears to be more challenging than for land animals, as fish myosystem types are more diverse and their idiosyncrasies less well characterized (Haard 1992). In addition to the fillets, the properties of skin, eyes, gills and mucus can affect the product's desirability, and fish quality measurements also take these into account. Regarding the specific organoleptic properties that are relevant to the definition of fish quality, the main focus has been given to concepts such as freshness, flavour, taste, aroma, texture and visual appearance. 'Freshness' is a special type of attribute that encompasses the other attributes, reflecting the apparent elapsed time since slaughter. Similarly, the concept of 'flavour' should also be seen as a meta-attribute (resulting of the interaction between 'taste', 'aroma' and 'texture', along with temperature and chemesthetic factors). The other attributes ('taste', 'aroma', 'texture' and 'visual appearance') can be seen as distinct aspects, although not necessarily independent, as there are common underlying factors to these distinct organoleptic properties.

The concept of 'taste' refers to the sensory information mediated through the gustative receptors of taste buds, which can be classified according to five known types (with distinct activation triggers): salty (alkali cations), sour (protons), sweet (saccharides and analogues), umami (L-glutamate, IMP, GMP) and bitter (hundreds of different substances) (Lindemann 1996). As expected, the subjective experience of taste can be mostly associated to the different free concentrations of gustative triggers present in the edible parts of fish, although there are also (human) genetic factors that might be determining to the ultimate perception of taste (particularly in the case of sweet and bitterness) (Mennella et al. 2005).

Regarding 'aroma', it basically concerns the olfactory perception elicited by volatile substances that are released both before and during mastication (Axel 1995). Like with 'taste', it results from a form of chemoreception, but mediated by olfactory receptor cells located inside the nasal cavity, along the olfactory epithelium. On the other hand, olfactory information is much richer than gustative information, as there is a wider range of different olfactory receptors than gustative receptors. Another difference between the two systems is that gustation requires direct physical contact of the reception organ (i.e. tongue) with the subject, unlike olfaction. The specific olfactory triggers in fish products include alcohols, aldehydes, ketones, esters, sulphides, mercaptans and amines. In the case of marine teleosts, the aroma of fresh fish is relatively simple and mostly composed of alcohols, aldehydes and ketones, which result from the activity of endogenous lipoxygenases on polyunsaturated fatty acids (Alasalvar et al. 2005; Iglesias et al. 2009). As time post-mortem elapses and spoilage begins, other types of more pungent volatiles start being produced mostly as a result of further oxidative processes and bacterial metabolism, namely dimethylamine, trimethylamine, sulphides, mercaptans, among others (Ashie et al. 1996; Ólafsdóttir \& Kristbergsson 2006).

Regardless of these differences, both types of chemoreceptive perception within the context of fish products are obviously highly dependent on body composition, but also post-mortem degradative processes, bacterial proliferation, lipid oxidation or any other processes that affect the composition of volatiles, fatty acids, small ions, nucleotides, free amino acids, saccharides and other substances. Even structural factors (i.e. 'texture') can have an influence on how taste and aroma develop, by modulating the release of these compounds before and during mastication, which is why it is often appropriate to consider a 'flavour' meta-attribute 
that results from and encompasses all these different interdependent aspects.

Another very important quality-defining attribute in fish products is 'texture', which is related to the mechanical perception of food in the mouth and therefore, in this particular case, to the structural and physical properties of the edible parts of fish. Descriptions of the textural properties of fish meat usually employ subjective organoleptic terms, such as firmness, chewiness, tenderness, juiciness and pastiness, that seem to be correlated to objective structural characteristics of meat, both in terms of initial apparent hardness and resilience in response to deformation forces, as in terms of secondary properties which only become apparent throughout the mastication process (e.g. springiness, cohesiveness, adhesiveness) (Coppes et al. 2002). In the specific case of fish, as already stated, there is a wide variability between species in terms of myotome organization and specific structural properties, although they generally display softer texture than land animals, due to their relatively sparse extracellular collagen matrix. Another general trend is that cultured fish also display generally softer texture than wild fish, which is seen as a negative attribute. In part, this is usually attributed to the fact that cultured fish are often constrained to a more sedentary lifestyle, which affects the development of their muscular system (Haard 1992). As such, the study of muscle physical properties and their relation to the subjective perception of texture, in the context of aquaculture, is given high importance.

Finally, 'visual appearance' is also an essential criterion in the assessment of fish quality, both in terms of a fish's external appearance (regarding, e.g. body shape, eye attributes, gill coloration and the presence of species-specific marks) as in terms of fillet colour (Poli 2009). Although appearance might seem like an attribute of lesser importance (in the sense that it generally does not affect much the flavour perception of fish products), it constitutes one of the main criteria consumers use to gauge product freshness, and significant deviations from consumers' expectations (e.g. in terms of body shape or flesh coloration) can prevent the marketability of fish, even if they display no spoilage or other compromised organoleptic traits. For some species (e.g. Atlantic salmon), it might be important to supplement their diets with specific crustacean- or algaederived pigments (in the case of salmonids, astaxanthin and other carotenoid pigments) which are usually present in their diet (in the wild), not only due to eventual nutritional/heath-related issues, but to enable the development of expected visual traits (e.g. meat coloration or specific external marks) that depend on the dietary availability of these pigments (Buttle et al. 2001).

Given the dependence of all these organoleptic traits on the physical and chemical properties of fish products, it should not be surprising that fish quality traits can be affected by a wide range of different factors, in a heavily species-dependent way. These factors can be classified according to whether they affect the premortem or intrinsic attributes of fish (which would reflect in measured quality parameters immediately post-mortem) and/or the postmortem temporal evolution of these traits (which would reflect on the rate of spoilage and deterioration of freshness-related attributes, in terms of quality traits measured several hours/days post-mortem). In the first case, we have factors related to nutrition, health, development and environment (e.g. temperature, photoperiod, salinity, $\mathrm{pH}$, water depth, $\mathrm{O}_{2}$ levels, $\mathrm{CO}_{2}$ levels, stocking density), which have been shown, in particular cases, to have a direct impact on fillet composition and physical properties and, therefore, on downstream quality attributes (Grigorakis 2007; Haard 1992). In the second case, it is important to take into account that, when fish are slaughtered, peripheral tissues (like skeletal muscle) begin to experience energy depletion and anoxia, as the circulatory system stops to provide oxygen and fuel. This leads to a cascade of tightly related processes and events which are characteristic of muscle-meat conversion and meat degradation (Fig. 3) and that can ultimately lead to changes in quality criteria, depending on how intensive and extensive these processes are (Poli 2009; Poli et al. 2005). At this level, several premortem and post-mortem factors are known to interact
Figure 3 Schematic representation of the different endogenous processes that occur in skeletal muscle post-slaughter, due to the onset of energy depletion and anoxia, which can ultimately affect the different organoleptic properties of fish products. For simplicity, exogenous processes (e.g. microbiological proliferation) were omitted.
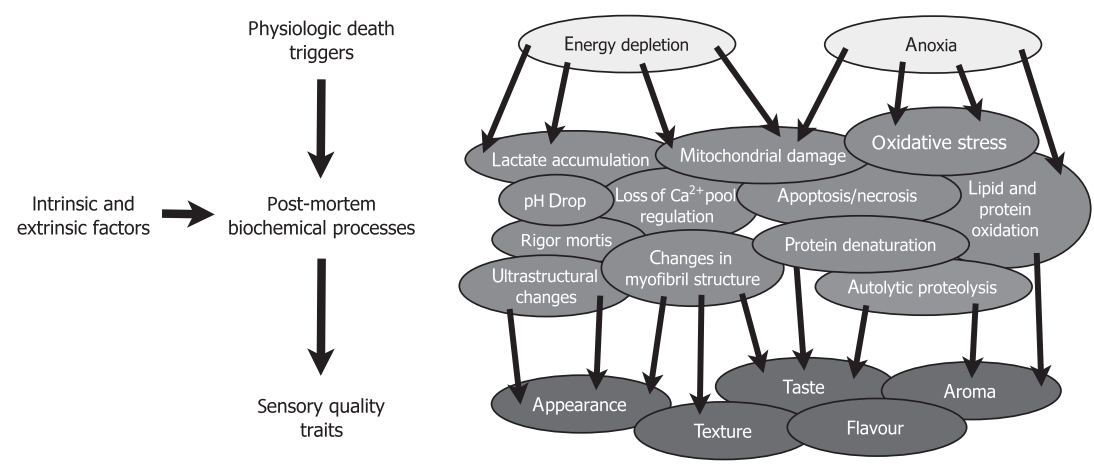
and influence the development of these processes: on one hand, as explained in the preceding section, there are factors related to fish nutrition and welfare (such as premortem energetic, metabolic and oxidative state and the type of harvesting and slaughtering methods used) (Huidobro et al. 2001; Poli et al. 2005; Tejada \& Huidobro 2002) and, on the other hand, we have factors which are related to the type of post-processing and conditioning used to manage post-mortem spoilage processes (Hall 1997; Sigholt et al. 2006). It is relevant to note that, while these postmortem conditioning processes generally tend to slow down spoilage (both in terms of autolytic processes and in terms of microbiological proliferation) and increase shelf life, they often also entail changes in terms of organoleptic properties (particularly in the case of salting, smoking, freezing, drying or freeze-drying), which obviously have to be taken into account. Although we cannot disregard the importance of the stage between slaughter and consumption (with temperature abuse during storage and transport playing an important role in seafood quality), Mediterranean species such as European sea bass and gilthead seabream are typically sold whole, so the farming stage assumes a great importance in the modulation of quality parameters relevant to the consumer. Regarding the assessment of fish quality itself, there are several possible complementary approaches, although the use of trained sensory panels is highly important (and generally seen as the 'golden standard'), regardless of other instrumental methods applied, since the latter generally fail to capture the whole range of information provided by human sensorial organs. Furthermore, the subjective perception of organoleptic traits (as it relates to consumers) is more readily apprehended through a sensory analysis performed by trained individuals than by instruments, as humans instinctively generate an integrated perception (e.g. flavour) from very differing types of stimuli (e.g. chemical, thermal, mechanical), which is something that purely instrument-based approaches might have difficulties with.

Given the difficulty of quantitatively assessing something which is inherently subjective, methods have been devised in an attempt to standardize species-specific quality evaluations, like the QIM (Quality Index Method) schemes (Huidobro et al. 2006; Hyldig \& Green-Petersen 2004). Other approaches, as already mentioned, rely on instrumental information to obtain objective measurements which can then be interpreted using both human knowledge-based and/or machine learning-based approaches. A specific example would be the use of data fusion methods on multi-instrumental data sets to achieve an objective index which possesses properties consistent with the QIM indicator (e.g. Ólafsdóttir et al. 2004).

Looking at the specific instrumentation that can be used to assess quality-related parameters in meat products, including fish products, it becomes clear there is a wide range of available complementary approaches to evaluate their physical and chemical properties (and, therefore, associated organoleptic attributes). Regarding physical properties, they are classically assessed using texture profile analysis or similar approaches that consist in measuring deformation behaviour as a function of (repeated) applied pressure, in an attempt to directly replicate the dynamics of mastication (Mochizuki 2001). Besides directly mechanical methods, other ways of assessing structural and physical properties are possible, from microwave imaging (e.g. Semenov 2009) to impedance (e.g. Ghatass et al. 2008) and calorimetric (e.g. Matos et al. 2011) measurements. There is also a great wealth of techniques (fluorescence anisotropy, circular dichroism and birefringence measurements) that exploit the fact that muscle tissue is optically active, due to its anisotropic nature, and the fact that some metabolites (like tryptophan) can act as intrinsic fluorophores, providing essential structural information (Damez \& Clerjon 2008). Unsurprisingly, many of the methods adopted by chemometrics/analytical chemistry are also used in the context of food quality assessment (e.g. mass spectrometry, nuclear magnetic resonance and FTIR spectroscopybased methods), as these are the most straightforward and comprehensive ways of obtaining thorough information on tissue and volatile chemical composition (Nilsen et al. 2002; Zhang \& Lee 1997). Apart from these, other indirect methods of assessing tissue composition can also be used (e.g. ultrasonic, X-ray and microwave imaging), as changes in tissue composition often entail predictable changes in measurable physical properties as well (Damez \& Clerjon 2008). Characterization of volatile composition is also increasingly being studied through the use of specialized arrays of sensors (generically dubbed 'electronic noses') (e.g. Ólafsdóttir et al. 2004). Besides all of these, several types of biochemical and microbiological assays are also employed, particularly in the assessment of fish freshness and safety.

In recent years, it became increasingly clear that the use of state-of-the-art 'omics' technologies (e.g. genomics, transcriptomics, metabolomics, proteomics) can also provide useful information on the impact of premortem factors (e.g. genetic, nutrition, welfare, development) on both the intrinsic (premortem) properties of skeletal muscle and its post-mortem degradation dynamics (e.g. Carrera et al. 2013; Terova et al. 2011; Silva et al. 2012a). Finally, there are signs that it might be possible to directly correlate quality traits with particular genes, transcripts or proteins (Picard et al. 2012), providing essential clues for a better understanding of the emergence of macroscopic organoleptic features from microscopic physicochemical properties. 


\section{How sustainable solutions are affecting gilthead seabream quality}

\section{Feeds: fish meal and fish oil replacement trend}

Although a considerable amount of research has been carried out in the past decades on the subject of fish meal and fish oil replacement on gilthead seabream diets, most studies focus, as expected, on the adequacy of the replacement ingredients used, namely growth performance and effects on fish health. Table 1 shows a summary of the studies performed with fish meal (FM) and fish oil (FO) replacement on aquafeeds for this species which evaluated some quality criteria in market-sized fish.

There is little information on the effects of fish meal replacement on quality aspects. Nonetheless, a few studies on fish oil replacement were carried out using diets with low levels (around 15\% of the formulation) of fish meal (Benedito-Palos et al. 2010, 2009; Fountoulaki et al. 2009; Grigorakis et al. 2009; Nasopoulou et al. 2011). When replacing $66 \%$ of FM with defatted soya bean meal only, a taste panel found the fillets to be less juicy (Martínez-Llorens et al. 2009). However, nowadays the main strategy for replacing FM with plant proteins (PP) is to use a blend of different vegetable sources, in order to minimize the impact of source-specific anti-nutritional factors. In a trial with up to $90 \%$ of FM replacement with a blend of pea and rice protein concentrates, the panellists were unable to detect differences in taste between treatments (Sánchez-Lozano et al. 2009), and muscle colour was not altered. Similarly, in a study in which $75 \%$ of FM was replaced with a blend of corn gluten meal, wheat gluten, peas and rapeseed meal, no differences were found in organoleptic properties (De Francesco et al. 2007). Nonetheless, the authors reported an increase in fillet lightness in plant protein-fed seabream. This study also evaluated the fatty acid profile of the muscle, and found that the use of plant proteins resulted in decreased MUFA, $n-3$ PUFA and $n-3$ PUFA/n-6 PUFA ratio, with a concomitant increase in n-6 PUFA, and this result was attributed to the fatty acid profile of the diets. Matos et al. (2012), in a study with replacement of $90 \%$ of FM (with or without concomitant replacement of $33 \%$ of FO with a blend 1:1 of soya bean oil [SO] and linseed oil [LO]) with a blend of vegetable ingredients, have shown that inclusion of high percentage of plant proteins in seabream diets does not impact fillet quality negatively, as no differences in instrumental texture were measured and there were only slight differences in fatty acid composition and muscle instrumental colour. Additionally, there was a slight but significant preference of the taste panel for seabream fed with vegetable ingredients (in terms of typical odour, fillet whiteness and succulence).

The data available on the use of land animal proteins in seabream are very scarce, especially due to the previous EU legislation, which severely limited its use on fish feeds (EC regulation 999/2001 of 22 May 2001, amended by EC regulation $1234 / 2003$ of 10 July 2003). EC regulation 56/2013 of 16 January 2013 reauthorized the inclusion of processed animal proteins from terrestrial animals in fish feeds, excluding ruminants, after 1 June 2013). Some data exist on the adequacy of such ingredients (specifically poultry and feather meals) in seabream feeds (e.g. Nengas et al. 1999; Nogueira et al. 2012), but no quality criteria were evaluated. A recent work by Ramalho-Ribeiro et al. (2013) evaluated the effect of simultaneous replacement of fish meal and fish oil with feather meal, haemoglobin and poultry fat in seabream quality. The growth performance of seabream was not affected by the diet with ingredients from terrestrial animals, and a trained taste panel did not detect any differences in terms of organoleptics, namely typical odour, white colour, taste and texture. Animal by-products have been regularly used as raw materials for fish feeds outside Europe for the past 20 years, and studies with species such as Atlantic salmon (Salmo salar L.) (Hatlen et al. 2013), silver perch (Bidyanus bidyanus Mitchell) (Allan \& Rowland 2005) or Japanese sea bass (Lateolabrax japonicus Cuvier) (Hu et al. 2013) have shown its acceptability in terms of sensory properties.

Novel protein sources are beginning to be investigated in several fish species, such as macroalgae and microalgae biomass (e.g. Vizcaíno et al. 2014; Xuan et al. 2013), mushrooms (e.g. Lawal et al. 2013), insect biomass (De Haro et al. 2015) or even sea cucumber meal (Piccino et al. 2013). Again, few studies focused on quality aspects; however, the inclusion of $15 \%$ insect meal (larvae from Lucilia sericata, Meigen) resulted in an increase in arachidonic acid in gilthead seabream (FBW $\approx 20 \mathrm{~g}$ ) muscle, as this insect is particularly rich in this essential fatty acid. Seabream growth was, however, negatively impacted (De Haro et al. 2015).

One of the main health benefits of fish consumption is the relatively high quantity of essential fatty acids it contains, especially $\mathrm{n}-3$ HUFA [such as eicosapentaenoic acid (EPA) and docosahexaenoic acid (DHA)], together with the correct balance between $n-3$ and $n-6$ HUFA (Turchini et al. 2009). Thus, it is not surprising that the great majority of studies on FO replacement in seabream diets that evaluated quality criteria focused on the evaluation of fillet fatty acid profile. Regardless of the oil source (or blends), the substitution of fish oil with vegetable oils will generally result in lower SFA and MUFA, lower $n-3$ PUFA, higher $n-6$ PUFA and lower $n-3$ PUFA/n-6 PUFA ratio in the muscle of seabream. The exception is the use of linseed oil in the feeds, as this vegetable oil is very rich in $\alpha$-linolenic acid $(\mathrm{C} 18: 3 \mathrm{n}-3)$. When using LO in seabream diets, $n-3$ PUFA in the muscle will increase, but not n-3 HUFA (like EPA and DHA). 
Table 1 Effect of fish meal and fish oil replacement on gilthead seabream quality criteria

\begin{tabular}{|c|c|c|c|c|c|}
\hline \% Replacement & IBW & FBW & DOT & $\begin{array}{l}\text { Observed quality } \\
\text { criteria changes }\end{array}$ & Reference \\
\hline $\begin{array}{l}60 \text { and } 80 \% \text { of FO with LO } \\
\text { or SO }\end{array}$ & $85 \mathrm{~g}$ & $441-464 \mathrm{~g}$ & $204 d$ & $\begin{array}{l}\text { - muscle FA: } \\
\downarrow \text { SFA and MUFA; } \uparrow \text { n-6 PUFA } \\
\downarrow n-3 \text { PUFA/n-6 PUFA ratio (SO diets) } \\
\text { - no effect on pH or instrumental texture } \\
\text { - muscle instrumental colour: } \\
\downarrow \text { a* and } b * \text { in fillet }\end{array}$ & $\begin{array}{l}\text { Menoyo et al. } \\
(2004)\end{array}$ \\
\hline 70 and $100 \%$ of FO with LO & $40 \mathrm{~g}$ & $496-507$ & $330 d$ & $\begin{array}{l}\text { - muscle FA: } \\
\downarrow \text { SFA; } \uparrow \text { n3 and n-6 PUFA } \\
\downarrow n-3 \text { HUFA and n-3 PUFA/n-6 PUFA ratio } \\
\text { - no effect on pH, TVBN, Torrimeter, QIM } \\
\downarrow \text { TBARS } \\
\text { - muscle instrumental texture: } \\
\text { no effect on raw fillets } \\
\text { cooked fillets: } \uparrow \text { springiness and resilience; } \downarrow \text { hardness, } \\
\text { cohesiveness, gumminess, adhesiveness and chewiness } \\
\text { - no differences detected by taste panel }\end{array}$ & $\begin{array}{l}\text { Castro et al. } \\
\text { (2013) }\end{array}$ \\
\hline $\begin{array}{l}60 \text { and } 80 \% \text { of FO with LO, } \\
\text { SO or RO }\end{array}$ & $85 \mathrm{~g}$ & $441-464 \mathrm{~g}$ & $204 d$ & $\begin{array}{l}\text { - muscle FA: } \\
\downarrow \text { SFA and } n-3 \text { HUFA; } \uparrow n-6 \text { PUFA } \\
\downarrow n-3 \text { PUFA/n-6 PUFA ratio } \\
\text { - no effect on pH or instrumental texture } \\
\text { - muscle instrumental colour: } \\
\downarrow a^{*} \text { and } b^{*} \text { in fillet } \\
\text { - taste panel (SO diet): } \\
\text { higher juiciness and adhesiveness } \\
\text { less hardness in the mouth, more earthy flavour }\end{array}$ & $\begin{array}{l}\text { Izquierdo et al. } \\
\text { (2005) }\end{array}$ \\
\hline $\begin{array}{l}33 \text { and } 66 \% \text { of FO with blend } \\
\text { of } \mathrm{VO}\end{array}$ & $18 \mathrm{~g}$ & 284-294 & $11 \mathrm{~m}$ & - muscle FA: & $\begin{array}{l}\text { Benedito-Palos } \\
\text { et al. (2009) }\end{array}$ \\
\hline $\begin{array}{l}\text { (RO+LO+PO) } \\
\text { Low FM diet ( } 15 \% \text { of formula) }\end{array}$ & & & & $\downarrow$ SFA and $n-3$ LC-PUFA & \\
\hline $\begin{array}{l}68.7 \% \text { of } \mathrm{FO} \text { with } \mathrm{SO}, \mathrm{PO} \text { or } \\
\mathrm{RO}\end{array}$ & $110 \mathrm{~g}$ & $260 \mathrm{~g}$ & $170 d$ & - muscle FA: & $\begin{array}{l}\text { Grigorakis et al. } \\
\text { (2009) }\end{array}$ \\
\hline $\begin{array}{l}\text { Low FM diet ( } 15 \% \text { of } \\
\text { formula) }\end{array}$ & & & & $\begin{array}{l}\downarrow n-3 \text { PUFA; } \uparrow n-6 \text { PUFA } \\
\downarrow \text { EPA and DHA } \\
\text { - no differences detected by taste panel }\end{array}$ & \\
\hline $\begin{array}{l}69 \% \text { of FO with SO, PO or RO } \\
\text { Low FM diet ( } 15 \% \text { of } \\
\text { formula) }\end{array}$ & $110 \mathrm{~g}$ & $230-260 \mathrm{~g}$ & $6 \mathrm{~m}$ & $\begin{array}{l}\text { - muscle FA: } \\
\downarrow n-3 \text { PUFA; } \uparrow \text { n-6 PUFA } \\
\downarrow n-3 \text { PUFA/n-6 PUFA ratio } \\
\text { - no differences detected by taste panel }\end{array}$ & $\begin{array}{l}\text { Fountoulaki et al. } \\
\text { (2009) }\end{array}$ \\
\hline $\begin{array}{l}60 \% \text { of FO with RO, SO, LO } \\
\text { or blend }\end{array}$ & $10 \mathrm{~g}$ & $63-69 \mathrm{~g}$ & $101 \mathrm{~d}$ & $\begin{array}{l}\text { - muscle FA: } \\
\downarrow \text { SFA; } \uparrow n-6 \text { PUFA } \\
\downarrow n-3 \text { LC-PUFA } \\
\downarrow n-3 \text { PUFA (SO and RO) } \\
\text { - no effect on instrumental texture } \\
\text { - taste panel: stronger taste and smell (SO only) }\end{array}$ & $\begin{array}{l}\text { Izquierdo et al. } \\
\text { (2003) }\end{array}$ \\
\hline $\begin{array}{l}33,66 \text { and } 100 \% \text { of } \mathrm{FO} \text { with } \\
\text { blend of } \mathrm{VO}(\mathrm{RO}+\mathrm{LO}+\mathrm{PO}) \\
\text { Low FM diet ( } 15 \% \text { of } \\
\text { formula) }\end{array}$ & $16 \mathrm{~g}$ & $240-270 \mathrm{~g}$ & $8 \mathrm{~m}$ & $\begin{array}{l}\text { - muscle FA: } \\
\downarrow \text { SFA and } n-3 \text { HUFA }\end{array}$ & $\begin{array}{l}\text { Benedito-Palos } \\
\text { et al. (2008) }\end{array}$ \\
\hline $\begin{array}{l}60 \% \text { of } \mathrm{FO} \text { with blend of } \mathrm{VO} \\
(\mathrm{SFO}+\mathrm{CO}+\mathrm{LO}+\mathrm{SO})\end{array}$ & $131 \mathrm{~g}$ & $352 \mathrm{~g}$ & $140 \mathrm{~d}$ & $\begin{array}{l}\text { - muscle FA: } \\
\downarrow \text { SFA; } \uparrow \text { PUFA }(n-3+n-6+n-9)\end{array}$ & $\begin{array}{l}\text { Wassef et al. } \\
\text { (2009) }\end{array}$ \\
\hline
\end{tabular}


Table 1 (continued)

\begin{tabular}{|c|c|c|c|c|c|}
\hline \% Replacement & IBW & FBW & DOT & $\begin{array}{l}\text { Observed quality } \\
\text { criteria changes }\end{array}$ & Reference \\
\hline $8 \%$ of FO with OP or OPO & $340 \mathrm{~g}$ & $466-542 \mathrm{~g}$ & $90 \mathrm{~d}$ & $\begin{array}{l}\text { - muscle FA: } \\
\text { OPO: } \uparrow \text { SFA } \\
\text { OP: } \downarrow \text { SFA, MUFA, n-3 PUFA, n-6 PUFA } \\
\text { and } n-3 \text { PUFA } n-6 \text { PUFA ratio } \\
\text { - health benefits: } \\
\text { OP enhanced cardioprotective properties }\end{array}$ & $\begin{array}{l}\text { Nasopoulou et al. } \\
\text { (2011) }\end{array}$ \\
\hline 70 and $100 \%$ of FO with LO & $40 \mathrm{~g}$ & $496-507 \mathrm{~g}$ & $330 d$ & $\begin{array}{l}\text { - muscle FA: } \\
\downarrow \text { SFA, MUFA and } n-3 / n-6 \text { ratio } \\
\uparrow n-3 \text { PUFA and } n-6 \text { PUFA } \\
\downarrow \text { EPA, DHA and ARA } \\
\text { - health: } \\
\downarrow \text { thrombogenic and atherogenic indices }\end{array}$ & $\begin{array}{l}\text { Castro et al. } \\
(2010)\end{array}$ \\
\hline $\begin{array}{l}66 \% \text { of } \mathrm{FO} \text { with blend of } \mathrm{VO} \\
\text { (RO+LO+PO) } \\
\text { Low FM diet ( } 15 \% \text { of } \\
\text { formula) }\end{array}$ & $18 \mathrm{~g}$ & $520-530 \mathrm{~g}$ & $14 \mathrm{~m}$ & $\begin{array}{l}\text { - muscle FA: } \\
\downarrow n-3 \text { LC-PUFA in neutral lipids fraction } \\
\text { no differences detected in phospholipids fraction }\end{array}$ & $\begin{array}{l}\text { Benedito-Palos } \\
\text { et al. (2010) }\end{array}$ \\
\hline 24-72\% FO with SO & $15 \mathrm{~g}$ & $325-349 \mathrm{~g}$ & $309 d$ & $\begin{array}{l}\text { - muscle FA: } \\
\downarrow \text { SFA and MUFA; } \uparrow n-6 \text { PUFA } \\
\downarrow n-3 \text { PUFA, n-3 HUFA and n-3 PUFA/n-6 PUFA ratio } \\
\text { - taste panel: } \\
\downarrow \text { greasiness, stickiness and fish flavour } \\
\uparrow \text { hardness and toughness }\end{array}$ & $\begin{array}{l}\text { Martínez-Llorens } \\
\text { et al. (2007) }\end{array}$ \\
\hline $\begin{array}{l}70 \text { and } 100 \% \text { of FO } \\
\text { with SO, LO or blend }\end{array}$ & $45 \mathrm{~g}$ & & $8 \mathrm{~m}$ & $\begin{array}{l}\text {-welfare: } \\
\downarrow \text { ability to deal with crowding stress } \\
\text { LO: } \uparrow \text { basal cortisol levels } \\
\text { SO: delayed cortisol response }\end{array}$ & $\begin{array}{l}\text { Ganga et al. } \\
(2011)\end{array}$ \\
\hline $\begin{array}{l}63 \% \text { of FO with BT } \\
100 \% \text { of FO with BT and } \\
\text { blend of VO (Corn oil }+ \\
\text { Linolenic acid) }\end{array}$ & $135 \mathrm{~g}$ & $255-282 \mathrm{~g}$ & $120 d$ & $\begin{array}{l}- \text { muscle FA: } \\
\uparrow \text { MUFA } \\
\uparrow n-6 \text { PUFA with VO blend } \\
\downarrow n-3 \text { PUFA and } n-3 \text { PUFA/n-6 PUFA } \\
- \text { health: } \\
\downarrow \text { atherogenic and flesh lipid quality indices } \\
\uparrow \text { thrombogenic index }\end{array}$ & Pérez et al. (2014) \\
\hline $\begin{array}{l}90 \% \text { of FM with blend of PP } \\
\text { and/or }\end{array}$ & $362 \mathrm{~g}$ & $431 \mathrm{~g}$ & $72 d$ & - muscle FA: & $\begin{array}{l}\text { Matos et al. } \\
(2012)\end{array}$ \\
\hline $\begin{array}{l}33 \% \text { of FO with blend of SO } \\
\text { and LO }\end{array}$ & & & & $\begin{array}{l}\uparrow \text { Linoleic acid with VO diets } \\
\downarrow n-3 \text { PUFA/n-6 PUFA ratio } \\
\text { - no differences in instrumental texture } \\
\text { - muscle instrumental colour: } \\
\downarrow \text { skin lightness with PP } \\
\text { - taste panel: } \\
\text { slight improvement in odour, colour } \\
\text { and succulence with PP }\end{array}$ & \\
\hline $\begin{array}{l}90 \% \text { of FM with blend of PP } \\
\text { and/or }\end{array}$ & $362 \mathrm{~g}$ & $431 \mathrm{~g}$ & $72 d$ & - higher muscle pH & $\begin{array}{l}\text { Matos et al. } \\
(2014)\end{array}$ \\
\hline $\begin{array}{l}33 \% \text { of FO with blend of SO } \\
\text { and LO }\end{array}$ & & & & $\begin{array}{l}\text { - lower sulphated glycosaminoglycans with PP } \\
\text { - lower proteolytic activity (cathepsin B) } \\
\text { - lower glycogen phosphorylase activity with PP }\end{array}$ & \\
\hline $\begin{array}{l}\text { 30, } 60 \text { and } 90 \% \text { of } F M \text { with } \\
\text { blend of PP } \\
\text { (PPC+RPC; AA } \\
\text { supplementation) }\end{array}$ & $174 \mathrm{~g}$ & $326-372 \mathrm{~g}$ & $80 d$ & $\begin{array}{l}\text { - muscle instrumental colour: } \\
\text { no differences detected } \\
\text { - no differences detected by taste panel }\end{array}$ & $\begin{array}{l}\text { Sánchez-Lozano } \\
\text { et al. (2009) }\end{array}$ \\
\hline $\begin{array}{l}13 \text { and } 66 \% \text { of FM with } \\
\text { defatted SBM }\end{array}$ & $242 \mathrm{~g}$ & $334-438 \mathrm{~g}$ & $134 d$ & - taste panel: less juiciness & $\begin{array}{l}\text { Martínez-Llorens } \\
\text { et al. (2009) }\end{array}$ \\
\hline
\end{tabular}


Table 1 (continued)

\begin{tabular}{|c|c|c|c|c|c|}
\hline \% Replacement & IBW & FBW & DOT & $\begin{array}{l}\text { Observed quality } \\
\text { criteria changes }\end{array}$ & Reference \\
\hline $\begin{array}{l}75 \% \text { of } \mathrm{FM} \text { with blend of PP } \\
\text { (CGM+WG+EP+RM) } \\
\text { AA supplementation } \\
\text { Added calcium } \\
\text { monophosphate }\end{array}$ & $100 \mathrm{~g}$ & $427-431 \mathrm{~g}$ & $12 \mathrm{~m}$ & $\begin{array}{l}\text { - muscle FA: } \\
\downarrow \text { MUFA, } n-3 \text { PUFA and } n-3 \text { PUFA/n-6 PUFA ratio } \\
\uparrow n-6 \text { PUFA } \\
\text { - health: } \\
\uparrow \text { thrombogenic index } \\
\text { - muscle instrumental colour: } \\
\uparrow \text { lightness in fillets } \\
\text { - no differences detected by taste panel }\end{array}$ & $\begin{array}{l}\text { De Francesco } \\
\text { et al. (2007) }\end{array}$ \\
\hline
\end{tabular}

Abbreviations: IBW - initial body weight; FBW - final body weight; DOT: duration of trial; FA - fatty acids; SFA - saturated fatty acids; MUFA - monounsaturated fatty acids; PUFA - polyunsaturated fatty acids; HUFA - highly unsaturated fatty acids; LC-PUFA - long-chain polyunsaturated fatty acids; EPA - eicosapentaenoic acid; DHA - docosahexaenoic acid; ARA - arachidonic acid; AA - amino acids; FO - fish oil; VO - vegetable oil; SO - soya bean oil; LO - linseed oil; RO - rapeseed oil; PO - palm oil; SFO - sunflower oil; CO - cottonseed oil; OP - olive pomace; OPO - olive pomace oil; BT - beef tallow; FM - fish meal; PP - plant protein; PPC - pea protein concentrate; RPC - rice protein concentrate; SBM - soya bean meal; CGM - corn gluten meal; WG - wheat gluten; EP - extruded peas; RM - rapeseed meal.

Although De Francesco et al. (2007) found that a diet high in plant proteins increased the thrombogenic index of seabream, thus lowering the health benefits of the fish, Castro et al. (2010), when replacing fish oil with up to $100 \%$ of LO reported lower thrombogenic and atherogenic indices for seabream fed these diets. However, plant proteins and vegetable oils are known to contain extremely low levels of micronutrients such as iodine, vitamin B12, A and D. Although the essentiality of these micronutrients is recognized for optimal fish nutrition, it has hardly been assessed if such 'vegetable formulations' are affecting the nutritional and health-promoting value of farmed fish. Seafood and n-3 PUFA are not absolute synonymous, as seafood actually contains 95-99\% of other nutrients that may also have health protective effects.

There is some inconsistency in the data reporting the effects of vegetable oils on organoleptic characteristics. Although some authors have found no differences with high replacement $(>60 \%)$ of FO with vegetable oils (soya bean, palm [PO] or rapeseed [RO] oils) on sensory properties (Fountoulaki et al. 2009; Grigorakis et al. 2009), one study states that the use of SO resulted in fillets of stronger taste and smell, compared to the use of FO, RO or LO, which were found to be similar by the taste panel (Izquierdo et al. 2003). In a study of longer duration (309 days, compared to 101-180 days of the previous studies) in which up to $72 \%$ FO was replaced with SO, the taste panel found the fillets from seabream fed soya bean oil were less greasy, less sticky and with a lower fish flavour, with increased hardness and toughness (Martínez-Llorens et al. 2007). Izquierdo et al. (2005) report that seabream fed diets with 60 and $80 \%$ FO replacement with SO possessed higher juiciness and adhesiveness, lower hardness in the mouth and a more earthy flavour, while seabream fed $60 \%$
RO and LO were not different from the FO control. Nonetheless, seabream fed with vegetable-based diets were generally well accepted by the taste panels.

Regarding other quality criteria, FO replacement with vegetable oils [VO] seems to have no effect of muscle instrumental texture (Izquierdo et al. 2003, 2005; Menoyo et al. 2004; Matos et al. 2012) and muscle $\mathrm{pH}$ at the time of death (Izquierdo et al. 2005; Menoyo et al. 2004). However, replacement of $90 \%$ of FM with $\mathrm{PP}$ and/or $33 \%$ of $\mathrm{FO}$ with $\mathrm{VO}$ can result in higher muscle $\mathrm{pH}$, measured $48 \mathrm{~h}$ post-mortem (Matos et al. 2014). Both Izquierdo et al. (2005) and Menoyo et al. (2004) measured muscle colour and observed a reduction in $a^{*}$ and $b^{*}$ values in the fillet in seabream fed LO or SO, compared to the FO control diet. Matos et al. (2014) measured a reduction in muscle sulphated glycosaminoglycans (SGAG) with PP in the diets. As components of the extracellular matrix, a lower content in SGAGs can theoretically result in textural alterations. These authors have also measured the activity of glycogen phosphorylase and proteolytic enzymes, and found that the high inclusion of vegetable ingredients causes alterations in early post-mortem metabolic processes and proteolytic potential that should be interpreted carefully. Izquierdo et al. (2003) evaluated the effect of replacing up to $100 \%$ of fish oil with either SO, LO or blends of these vegetable oils on the ability of seabream to deal with crowding stress, and found that feeding linseed oil resulted in higher basal plasma cortisol levels, while using soya bean oil delayed the cortisol response of the fish after the stressful event, thus showing that fish oil replacement can impact fish welfare negatively. In a study with up to $100 \%$ replacement of FO with LO, it was reported that high levels of $n-6$ fatty acids induce imbalances on the immune response of gilthead seabream that result in 
lower ability to resist infectious pathogens (Montero et al. 2010). Nácher-Mestre et al. (2009, 2010) studied the effect of a blend of VO (up to $66 \%$ replacement) on feedborne contaminants (as marine ingredients are considered the main source of pollutants in the human diet) in seabream diets and seabream muscle, specifically polychlorinated biphenyls, dioxin-like PCBs, organochlorine pesticides and polycyclic aromatic hydrocarbons, and found that the amount of some of these substances decreased in the diets with the increase in VO levels, although even the fish oil control diet had very low levels of contaminants. This study shows a possible benefit of VO use in fish diets, regarding product safety.

To the best of our knowledge, there is little data available on the possible effects on quality aspects of the use of land animal fats in gilthead seabream diets. RamalhoRibeiro et al. (2013) replaced around 75\% of the fish oil in the diet with poultry fat in seabream diets. Although, as previously mentioned, there were no differences in terms of organoleptic properties, the authors observed a significant decrease in the $n-3 / n-6$ ratio, mostly due to a decrease in PUFA levels in the muscle. This effect is similar to what is seen with vegetable oils, and we can postulate that the inclusion of rendered animal fats will most likely result in changes in muscle lipid profile, but little changes in organoleptic properties of the fish, as is seen with other species. Pérez et al. (2014) have shown that a blend of beef tallow and fish oil (2:1) was able to maintain growth in seabream without significantly lowering the HUFA levels in the fillet. Recent trials with diets including rendered animal fats have shown that the sensory properties and nutritional value of Atlantic salmon (Hatlen et al. 2013) and rainbow trout (Trushenski et al. 2011) are not greatly impacted by the inclusion of this type of ingredients. A good alternative to fish oil would be the use of microalgae oils, specifically from species rich in $n-3$ HUFA (such as Schizochytrium sp., Isochrysis sp. or Crypthecodinium cohnii). At present, these ingredients are still too expensive to use in grow-out feeds and are only routinely used for larvae. The improvement of production technologies could lead to the widespread utilization of microalgae oils in aquaculture, potentially solving the fish oil shortage problem. Mesopelagic fish, such as lantern fish, are another potential alternative $n-3$ HUFA source for use in aquaculture feeds. These species live at depths between 200 and $1000 \mathrm{~m}$, and preliminary catches showed that lantern fish contained $25 \%$ total fatty acids as EPA and DHA. However, mesopelagic oils present a high proportion of lipids in the form of wax esters. Wax esters are toxic to humans in large amounts, but may be well utilized by fish. If wax esters can totally replace fish oils, vast amounts can be extracted from the seas, and 'unhealthy' fat can be converted into 'healthy' fat. Global estimates put the lantern fish biomass at around 600 million ton worldwide.

In general, the effects of FM and FO replacement on quality criteria will depend on the specific ingredients used, but overall, the main alteration will be the fatty acid profile of the fillets, and consequently, the potential health benefits seabream offers to the consumer. Organoleptic properties (with the exception of seabream fed diets with high inclusion of soya bean ingredients), instrumental texture and fillet colour, suffer little change with the use of vegetable ingredients. Further studies are needed to evaluate the effect of land animal-based diets on seabream quality, and also to evaluate the impact FM and FO replacement have on seabream welfare.

\section{Tailoring: finishing strategies}

Most strategies designed to tailor gilthead seabream quality criteria using nutritional modulation have focused on replacing diets low on fish oil (used during the grow-out phase) with high $n-3$ HUFA diets, in order to restore the flesh lipid profile and guarantee the high nutritional value of the fish. Studies show that the restoration of flesh fatty acid profile will follow a dilution model, with gradual changes occurring during the re-feeding period. However, these changes are usually not sufficient to restore important fatty acid classes (such as n-3 HUFA) to levels measured in seabream fed high fish oil diets continuously. BeneditoPalos et al. (2009) have shown that, after re-feeding seabream (previously fed with diets with 33 or $66 \%$ of FO replaced with a blend of VO), fatty acids (FAs) which are present in higher amounts in fish oil will progressively increase in the muscle (i.e. 14:0, 16:1 n-7, 20:1 n-9, 22:1 $\mathrm{n}-11$, EPA and DHA), while those characteristic of vegetable oils (i.e. 18:1 n-9, 18:2 n-6 and 18:3n-3) will decrease. These authors propose that this type of finishing strategy should be applied during fast growth periods (summer), as the structural lipid fraction (phospholipids) of the muscle is more conserved and this would stimulate retention of FAs such as EPA and DHA (Benedito-Palos et al. 2009, 2010). In a similar study, in which seabream were fed diets with $69 \%$ of FO replaced with either SO, PO or RO, a finishing diet (control diet) fed for 4 months was not enough to restore levels of DHA and EPA completely, while linoleic and oleic acids were retained in the muscle (Fountoulaki et al. 2009). Martínez-Llorens et al. (2009) replaced fish meal with defatted soya bean meal (SBM) in proportions ranging from 13 to $66 \%$ of FM. Sensory analysis showed that the panellists found seabream fed SBM less juicy; however, after 28 days of re-feeding with a finishing diet (control diet), this difference disappeared. Izquierdo et al. (2005), in an experiment where seabream previously fed diets with either 60 or $80 \%$ FO replacement with 
vegetable oils were re-fed with a FO diet for 90 days, found that although the amounts of linoleic and linolenic acid in the muscle lowered during re-feeding, this reduction was not sufficient to reach the levels of seabream fed FO diets throughout the grow-out phase. Nevertheless, levels of DHA and arachidonic acid (ARA) in the muscle were restored after 60 days of re-feeding, even if the same cannot be said for EPA levels.

A more innovative nutritional modulation approach is the use of dietary supplements to improve quality criteria, measured during shelf livf (Álvarez et al. 2012). In this study, the authors supplemented seabream diets with antioxidant compounds, natural and synthetic (namely BHT, rosemary extract, carvacrol and thymol), during a period of 18 weeks. The use of these supplements resulted in some slight alterations in terms of skin and flesh colour, but the major improvements noted were a reduction in lipid oxidation at the end of the shelf life with the use of $\mathrm{BHT}$, rosemary extract and carvacol and a reduction in microbiological counts with the use of thymol and carvacol. Overall, the authors state that, compared to the control-fed seabream, seabream fed rosemary extract and carvacol had one additional day of shelf life, while seabream fed BHT and thymol had two additional days of shelf life, according to the QIM results. Similar studies used feeds supplemented with rosemary or thyme extracts to improve seabream shelf life. A supplementation of $600 \mathrm{mg} \mathrm{kg}^{-1}$ of rosemary extract in the feed, supplied for 12 weeks prior to slaughter, was able to increase shelf life for 1 day (Hernández et al. 2014a). The same effect was achieved after feeding seabream for 12 weeks with $500 \mathrm{mg} \mathrm{kg}^{-1}$ of thyme essential oil (Hernández et al. 2014b). Matos et al. (2013) supplemented seabream diets with maslinic acid, to modulate glycogen post-mortem mobilization in the muscle and delay post-mortem degradation, through the reported inhibition this compound exerts over glycogen phosphorylase. Although these authors have not seen the expected increase in muscle glycogen and ATP levels, and glycogen phosphorylase activity remained unaltered, they have shown an increase in muscle hypertrophy and a reduction in cathep$\sin \mathrm{B}$ activity, which indicate a potential of this supplement for growth improvement through the modulation of protein turnover in the muscle. With the same purpose of improving muscle glycogen levels and delay post-mortem degradation, Silva et al. (2012b) have supplemented seabream diets with crude glycerol. This supplementation resulted in higher ATP and glycogen levels in post-mortem muscle, higher muscle $\mathrm{pH}$ at the time of death and higher fillet yield. However, most of the quality parameters measured (instrumental texture and colour, sensory evaluation, aroma analysis, lipid oxidation and proteolytic activity) were not affected by the inclusion of glycerol in the diet. Ramalho Ribeiro et al. (2015) fed seabream for 118 days with different iodine sources, including the macroalgae Laminaria digitata. The authors have shown that a natural source of iodine such as macroalgae is capable of significantly increasing the iodine content of the fillets without a negative impact on organoleptic properties. One common practice in seabream farming is feeding interruption prior to slaughter. Although it is done primarily to empty the fish gut (which will have a positive impact on post-mortem deterioration, by lowering the activity of digestive enzymes) and prevent water quality deterioration during harvest, it is also believed that a period of fasting prior to catch will result in lower perivisceral fat, which is an attractive trait for the consumer (Grigorakis \& Alexis 2005). These authors analysed seabream starved for up to 3 weeks prior to slaughter and conclude that starvation for a period of 2-3 weeks 'can generally improve the final product quality'. However, it must be stated that the only quality criteria with relevance for the consumer that were measured were muscle, perivisceral and peritoneal fat (which show a reduction with the duration of fasting), and this seems hardly enough to state that product quality was improved. In a study with up to $72 \mathrm{~h}$ of starvation, in which the shelf life of the fish was followed for 21 days, longer starvation periods resulted in lower muscle $\mathrm{pH}$, reduction in muscle instrumental texture (cohesiveness of the fillets), higher QIM and microbiological counts, and the authors conclude that even a period as short as $72 \mathrm{~h}$ of starvation will accelerate post-mortem deterioration of the muscle and limit the product's shelf life (Álvarez et al. 2008). Ferreira Pinto et al. (2007) studied the effects on product quality in seabream starved for up to 13 days and concluded that after 7 days of starvation there was a reduction in perivisceral fat. There were no trends in FAs profile and colour of the muscle regarding starvation, and sensory analysis (both raw and cooked) showed no differences. Nonetheless, the authors only measured these parameters on fresh fish and state that the evolution of shelf life can be potentially affected by starvation. A study with seabream starved for up to 8 days prior to slaughter has shown that there are some positive effects in flesh texture with starvation (specifically the force needed to puncture the whole fish, as the textural parameters measured on fish fillets suffered no changes) (Ginés et al. 2002).

In summary, finishing strategies to restore essential FA are not completely effective, although we have to mention that seabream fed with vegetable-based diets will still retain a high nutritional value (Izquierdo et al. 2005). The effects of starvation on flesh quality are not fully known, and it must be taken in consideration that long periods of starvation in aquaculture fish are considered inhumane by the European Food Safety Authority and should be avoided (EFSA 2009). Information regarding the use of dietary supplements as finishing strategies to modulate post-mortem 
degradation overall flesh quality criteria in seabream muscle is still extremely scarce.

\section{Farming practices: stressful events at slaughter}

Regardless of the production system, commercial harvesting procedures for gilthead seabream are relatively similar, usually involving netting the fish and keeping it confined for a period of time prior to slaughter, and subsequent slaughter, generally with a mixture of ice and salt water (ice-water slurry). The effects these procedures have on seabream welfare and overall quality have been investigated in the last years. Although little information is available on the effects of crowding stress prior to slaughter, Bagni et al. (2007), in a study where seabream were kept at a high density ( $70 \mathrm{~kg} \mathrm{~m}^{-3}$ for $3 \mathrm{~h}$ ), have shown that, in crowded fish, rigor mortis starts and resolves earlier, and initial muscle $\mathrm{pH}$ is lower than for uncrowded fish, while the production of reactive oxygen metabolites and the antioxidant power were not affected by crowding stress. Similarly, Matos et al. (2010) have shown that seabream crowded prior to slaughter will attain full rigor $2 \mathrm{~h}$ after death, while seabream subjected to anaesthesia prior to slaughter will only reach full rigor between 12 and $21 \mathrm{~h}$ after death. Additionally, Ortuño et al. (2001) have shown that crowding stress (seabream kept at $100 \mathrm{~kg} \mathrm{~m}^{-3}$ for $2 \mathrm{~h}$ ) results in higher plasma cortisol and glucose levels, as well as decreased phagocytic activity, and concluded that crowding induced depression of the innate immune system. This is especially relevant if we consider that usually a seabream pond or net pen will not be harvested completely on one single occasion but rather can be subjected to repeated crowding and harvesting procedures, for a period that can last several weeks.

Besides the traditional use of ice-water slurry, several killing procedures have been proposed for gilthead seabream. Bagni et al. (2007) compared seabream slaughtered with either chilled water or asphyxia in air and concluded that both methods were highly stressful. Huidobro et al. (2001), in a study where liquid ice was compared with the more common ice-water slurry, concluded that although liquid ice resulted in some improvement in textural parameters (possibly due to the fact that seabream from this treatment were in rigor during a longer period), it also increased the QIM score, mainly due to clouding of the eyes. A taste panel found no differences between treatments. Another study using liquid ice (Urbieta \& Ginés 2000) showed also improved textural parameters (higher firmness of fillets). These authors found no differences in terms of skin colour due to the slaughter method used, but reported a lower $\mathrm{k}$-value for seabream slaughtered with liquid ice and, consequently, improved freshness parameters. Both studies state that one of the main advantages of using liquid ice is the fact that seabream struggle less, die more rapidly and muscle temperature drops faster and remains lower than with ice-water slurry. When using water with $\mathrm{CO}_{2}$ as a killing procedure, Giuffrida et al. (2007) have found that this method was less stressful compared to ice-water slurry, particularly because it resulted in a lower ATP/IMP ratio. The treatments used showed no differences in terms of muscle $\mathrm{pH}$ or microbiological counts. However, fish slaughtered using $\mathrm{CO}_{2}$ had higher muscle lipid oxidation, which is a negative trait. Tejada and Huidobro (2002) have tested percussive stunning in conjunction with ice-water slurry and compared this method with ice-water slurry only or asphyxia in air. Asphyxia resulted in the lowest scores in sensory analysis (flavour of cooked fillets), higher microbiological counts in the first 12 days of storage and one day less of shelf life, compared to the other two methods. Percussive stunning followed by ice-water slurry, however, resulted in delayed onset of rigor mortis, lower lipid oxidation in the muscle and lower microbiological counts in the first 12 days of storage. The authors reported no differences in terms of muscle $\mathrm{pH}$, trimethylamine oxide nitrogen, trimethylamine nitrogen and total volatile basic nitrogen in relation to the slaughtering method, and concluded that the slaughter method had no clear influence on seabream quality, possibly because the highly stressful harvesting procedures masked the effect on seabream quality. Silva et al. (2012a) attempted to isolate the effect of crowding stress, comparing the muscle's proteomic profile of seabream either subjected to crowding or a profound anaesthesia that were subsequently slaughtered using a lethal dose of anaesthetic. These authors have shown that preslaughter crowding stress affects several proteolytic pathways, as well the response to oxidative stress and energy homoeostasis processes, generally pointing towards a hastening of the post-mortem degradation process. Matos et al. (2011) used differential scanning calorimetry to evaluate muscle protein degradation in seabream subjected to crowding stress, using anaesthetized seabream as control, and have found that the intense exercise prior to slaughter (during crowding procedures) promoted partial denaturation of myosin in the muscle.

New alternatives for common harvesting and slaughter methods are needed for seabream industrial production in order to improve welfare, as traditional methods are clearly stressful for seabream. Slaughter methods such as asphyxia in air are among the most stressful killing procedures and should be avoided, even in research.

\section{Production systems: semi-intensive, intensive, IMTA, organic production}

Although the largest amount of seabream production in the European market comes from intensive production (sea 
cages), there is still a large production from land-based semi-intensive and extensive systems, mainly from Spain and Portugal. There is some evidence that seabream from different rearing systems have different characteristics; however, very little information exists regarding the effects of different rearing systems on seabream flesh quality.

Orban et al. (1997) compared seabream from an intensive farming system (concrete tanks, commercial diet) with extensively farmed seabream (earth ponds, natural food only), and found that intensively farmed seabream had a higher lipid content in the muscle, and were considered by a taste panel to be more fresh, have higher juiciness and greasiness and lower fibrousness than the extensively farmed fish. However, instrumental texture showed lower firmness and force required to puncture the fillets from intensive farming. A similar study (Meloni 2010) showed that seabream from offshore cages had a higher lipid content in the muscle, but the fatty acid profile of the muscle showed also a lower percentage of SFA and MUFA, a higher percentage of $n-3$ and $n-6$ PUFA (although the $n-3$ PUFA/n-6 PUFA ratio was lower), a higher content in EPA and a lower thrombogenic index, compared to seabream farmed extensively in a costal lagoon. Fagioli et al. (2009) compared seabream reared in an intensive recirculating system, seabream from valliculture and seabream reared in offshore cages and found that, although there were no significant differences throughout storage time in terms of QIM and Torry scheme measurements, seabream from cages had generally high flesh $\mathrm{pH}$ and lower water holding capacity. Quality criteria of seabream from three different rearing systems (one intensive, in fibreglass tanks, maximum density $60 \mathrm{~kg} \mathrm{~m}^{-3}$; two semi-intensive, in earth ponds, maximum density of either $3 \mathrm{~kg} \mathrm{~m}^{-3}$ or $0.75 \mathrm{~kg} \mathrm{~m}^{-3}$ ) were evaluated by Flos et al. (2002), and the results show that seabream from both semi-intensive systems were similar in terms of colour, freshness and overall appearance, while intensively reared fish were found to be less fresh (mainly due to a worse appearance of the skin and presence of outer slime) and lacked the interorbital yellow line characteristic of this species. Seabream from intensive farming also had higher muscle $\mathrm{pH}$. Roncarati et al. (2006) have shown that seabream reared in semiintensive earth ponds $\left(0.2 \mathrm{~kg} \mathrm{~m}^{-3}\right)$ have lower cholesterol and triglycerides and a higher content in n-3 PUFA in the muscle, compared with seabream reared intensively in concrete raceways (20 and $40 \mathrm{~kg} \mathrm{~m}^{-3}$ ). The authors have also shown that very high densities $\left(40 \mathrm{~kg} \mathrm{~m}^{-3}\right)$ result in poor welfare conditions for seabream. Valente et al. (2011) collected seabream from different farming systems, namely extensive (with production ranging from 100 to $500 \mathrm{~kg} \mathrm{ha}^{-1}$ year $^{-1}$ ), semi-intensive (earth ponds, density: $0.5-4.5 \mathrm{~kg} \mathrm{~m}^{-2}$ ), intensive (both offshore cages and earth ponds, density: $\left.10-70 \mathrm{~kg} \mathrm{~m}^{-3}\right)$, and from integrated multitrophic aquaculture (IMTA), where seabream previously grown in an intensive farm were transferred, near market size, to algae ponds, where they were kept for up to 6 months at low densities (around $0.3 \mathrm{~kg} \mathrm{~m}^{-2}$ ). Their results show that seabream muscle from IMTA systems had a darker and yellower colour (lower $L^{*}$, higher $b^{*}$ ), and seabream from both IMTA and extensive rearing had very strong interorbital yellow lines, as well as an orange patch near the operculum, while seabream from intensive systems had whiter flesh, muscle texture was considered more dense and fibrous, stickier and firmer and the fish lacked the characteristic yellow and orange marks. Fish from semi-intensive production showed intermediate characteristics. In terms of odour, seabream from IMTA had a strong marine odour and seabream reared extensively had an earthy odour and flavour, while intensively reared seabream had a fattier odour. Richard et al. (2010) have shown that a short stay (2-6 months) in algae ponds can result in lower lipid content in the fillets and higher EPA, docosapentaenoic acid (DPA) and DHA. Additionally, seabream will show a more intense interorbital yellow line, a more intense orange mark near the operculum, and the fillets (both raw and cooked) will have a darker and yellower colour, compared to intensively farmed seabream. Sensory analysis described seabream from IMTA system as having a more marine-iodine-like flavour, while intensive fish were considered to have a fattier odour. In general, seabream from intensive farming are less colourful and fattier than seabream from other production systems, and the intensity of the interorbital yellow line is one of the simpler ways to distinguish seabream from different production systems. The high densities practised in intensive systems can pose welfare concerns which should be further investigated.

It is a challenge to assess the potential effects of organic production on seabream quality. The paucity of available studies, combined with the multiplicity of variables that change simultaneously (quality of fry, stocking densities, feed formulations, etc.), can result in quality changes that are then difficult to trace to a particular cause. For instance, the work of Mente et al. (2012), one of the few available studies with gilthead seabream, showed that organically produced seabream had higher growth, moisture and protein content and lower muscle lipid content. However, the higher growth can be a result of the lower stocking densities used or of the quality of the organic feed. Similarly, the lower lipid content of the muscle can derive not from the fact that organic ingredients were used but most likely from the fact that the organic feed used had a lower crude lipid content ( $14 \%$ vs. $17 \%$ in the conventional feed). A similar study by Marino et al. (2014) only studied the effects of the feed. Both organic and conventional feeds were available commercially, and the composition is not reported. Again, 
organic seabream had a higher growth performance, but this can result either from the use of organic ingredients or from the feed proximal composition. Nonetheless, the authors report a lower level of $n-3$ PUFA and a lower $\mathrm{n}-3 / \mathrm{n}-6$ FA ratio in organic seabream, and attribute this result to the higher content of linoleic acid in the muscle, reflecting feed ingredient composition. There were no differences in terms of welfare indicators or sensory parameters, and both conventional and organic seabream had a similar shelf life. Although the Commission Regulation No 710/2009 (European Union 2009) lays down rules for the feeding of carnivore and noncarnivore fish, it does not specify in which class is gilthead seabream to be included. Assuming it is considered a carnivore fish, feeds can include up to $60 \%$ of vegetable ingredients. However, this inclusion is severely limited by the prohibition to use synthetic amino acids to balance the feeds. As such, it is expected that organic feeds will have a higher content of fish meal than conventional feeds. Trocino et al. (2012) compared European sea bass from conventional and organic production and found that the lipid profile of the conventional diets was consistent with the use of vegetable ingredients to replace fish meal and oil, while the organic diets contained less vegetable ingredients, due to the lower availability of certified organic vegetable raw materials. The authors found that while proximate composition of the fillets was not affected by the organic diet, the fatty acid profile changed according to the fatty acid profile of the diets. Even though few studies are available, we postulate that the impact of organic farming on most intrinsic fish quality attributes (i.e. nutritional value, search and experience attributes) will most likely be due to the changes in practices and feed formulations rather than from the fact that organic ingredients are used in the feeds. More specifically, one would expect some quality improvement resulting from better welfare management. Similarly, changes in fillet quality can be expected to be similar to the ones observed in other fish meal and oil replacement studies, already discussed in section 4.1. The legal limitations on the use of antibiotics and other chemicals can also have a positive effect on quality, specifically on food safety issues. Finally, it is important to have into account that, independently of the benefits at the level of intrinsic product quality, there is an added benefit resulting from the consumer's positive perception of 'organic' products that, although not easy to quantify, it is not negligible. Thus, if we think of fish quality in its broadest sense (i.e. taking into account all factors that determine how consumers assess product value), the concept of 'organic fish' could be a successful strategy to address sustainability at all levels (environmental, economic and social). Nonetheless, this depends not only on having all the necessary regulatory framework and control/traceability/certification processes in place, but also in educating and explicitly informing the consumer during the act of purchase.

\section{Future perspectives}

Gilthead seabream is one of the most important farmed species in the Mediterranean, and yet, our knowledge on how specific farming practices impact its quality is still scarce. The replacement of marine-derived ingredients with vegetable sources does not greatly impact flesh organoleptic properties and adequate levels of essential fatty acids of the omega-3 series can still be achieved. However, health benefits resulting from fish consumption do not result exclusively of the adequate intake of PUFAs but also of the many micronutrients and vitamins present in fish that are essential to our health. These nutrients, such as iodine, vitamins A, D and of the B family, are not present in most vegetable ingredients used in compound feeds today, and a further understanding on how they impact seabream flesh quality is still necessary.

Although most land animal proteins and fats were banned from feeds in the beginning of this century, we have seen a gradual reintroduction of this type of ingredient, although with some restrictions. Blood meals and hydrolysed animal proteins have been authorized in 2003 and are common in compound feeds, and the ban on nonruminant processed animal proteins was lifted during 2013. Although we already have some information on the performance of these types of feeds in gilthead seabream, it is essential that the effects of ingredients from land animals are assessed from a consumer quality perspective.

The modern consumer is increasingly aware of welfare issues concerning livestock production in general and, more recently, aquaculture production. The demand for cruelty-free foods has been increasing in the past years and will probably continue to do so in the future. Even though seabream texture is resistant to high stress levels (contrary to what is seen in most farmed fish species), this is obviously not a valid reason to continue to use the traditional methods of slaughter, which are highly stressful. The use of anaesthetics such as isoeugenol could be a viable alternative to slaughter with ice-water slurry, or at least a way to minimize stress prior to slaughter. However, no anaesthetic is currently approved in the EU to be used as a slaughter or rested-harvest method in fish for human consumption. Research on new cruelty-free slaughter methods is therefore necessary. Additionally, mostly in semi-intensive production, there is still a need to develop and standardize harvesting procedures.

The concept of using a finishing strategy to improve flesh quality is relatively new in fish and, as we have seen, most of the research focus on restoring PUFA levels at the end of the life cycle, when seabream has been previously fed low 
fish oil diets. Restoration of PUFA to acceptable levels is possible, but is an extremely ineffective process. As such, it would be interesting to further research the mechanisms behind fatty acid deposition and, moreover, find nutritional strategies to optimize this deposition that allow for a lower usage of fish oil in finishing diets. Obviously and as was pointed out before, although PUFAs are very important in human nutrition, other nutrients are also very relevant and research on finishing strategies to improve the levels of specific micro-nutrients and vitamins characteristic of fish is still needed.

In summary, although some trade-offs have to be made while pursuing sustainable fish farming, it seems possible to address most issues, while still maintaining a high quality and high health value in aquacultured products.

\section{Acknowledgements}

Elisabete Matos benefited from grant SFRH/BD/40886/ 2007 (FCT, Portugal). Tomé S. Silva benefited from grant SFRH/BD/41392/2007 (FCT, Portugal).

\section{References}

Adams WM (2006) The Future of Sustainability. Re-Thinking Environment and Development in the Twenty-First Century. World Conservation Union - IUCN, Gland, Switzerland.

Alasalvar C, Taylor KDA, Shahidi F (2005) Comparison of volatiles of cultured and wild sea bream (Sparus aurata) during storage in ice by dynamic headspace analysis/gas chromatography-mass spectrometry. Journal of Agricultural and Food Chemistry 53: 2616-2622.

Allan G, Rowland SJ (2005) Performance and sensory evaluation of silver perch (Bidyanus bidyanus Mitchell) fed soybean or meat meal-based diets in earthen ponds. Aquaculture Research 36: 1322-1332.

Álvarez A, García BG, Garrido MD, Hernández MD (2008) The influence of starvation time prior to slaughter on the quality of commercial-sized gilthead seabream (Sparus aurata) during ice storage. Aquaculture 284: 106-114.

Álvarez A, García BG, Jordán MJ, Martínez-Conesa C, Hernández MD (2012) The effect of diets supplemented with thyme essential oils and rosemary extract on the deterioration of farmed gilthead seabream (Sparus aurata) during storage on ice. Food Chemistry 132: 1395-1405.

Álvarez-Chávez CR, Edwards S, Moure-Eraso R, Geise K (2012) Sustainability of bio-based plastics: general comparative analysis and recommendations for improvement. Journal of Cleaner Production 23: 47-56.

Amerio M, Ruggi C, Badini C (1996) Meat quality of reared fish: nutritional aspects. Italian Journal of Food Science 8: 221-229.

Anastasiou S, Nengas I (2005) A general review on the use of alternative protein sources in diets for Mediterranean fish. Cahiers Options Méditerranéennes 63: 121-126.
Ashie I, Smith J, Simpson B, Haard DNF (1996) Spoilage and shelf-life extension of fresh fish and shellfish. Critical Reviews in Food Science \& Nutrition 36: 87-121.

Axel R (1995) The molecular logic of smell. Scientific American 273: $154-159$.

Bagni M, Civitareale C, Priori A, Ballerini A, Finoia M, Brambilla G, et al. (2007) Pre-slaughter crowding stress and killing procedures affecting quality and welfare in sea bass (Dicentrarchus labrax) and sea bream (Sparus aurata). Aquaculture 263: 52-60.

Benedito-Palos L, Navarro JC, Sitjà-Bobadilla A, Bell JG, Kaushik S, Pérez-Sánchez J (2008) High levels of vegetable oils in plant protein-rich diets fed to gilthead sea bream (Sparus aurata L.): growth performance, muscle fatty acid profiles and histological alterations of target tissues. British Journal of Nutrition 100: 992-1003.

Benedito-Palos L, Navarro JC, Bermejo-Nogales A, Saera-Vila A, Kaushik S, Pérez-Sánchez J (2009) The time course of fish oil wash-out follows a simple dilution model in gilthead sea bream (Sparus aurata L.) fed graded levels of vegetable oils. Aquaculture 288: 98-105.

Benedito-Palos L, Navarro JC, Kaushik S, Pérez-Sánchez J (2010) Tissue-specific robustness of fatty acid signatures in cultured gilthead sea bream (Sparus aurata L.) fed practical diets with a combined high replacement of fish meal and fish oil. Journal of Animal Science 88: 1759-1770.

Brundtland GH (1987) Report of the World Commission on Environment and Development: Our common future. Oxford University Press, Oxford.

Buttle L, Crampton V, Williams P (2001) The effect of feed pigment type on flesh pigment deposition and colour in farmed Atlantic salmon, Salmo salar L. Aquaculture Research 32: 103-111.

Carrera M, Cañas B, Gallardo JM (2013) Proteomics for the assessment of quality and safety of fishery products. Food Research International 54: 972-979.

Castro PL, Caballero MJ, Millán R, Ginés R, Montero D, Izquierdo M (2010) Linseed oil inclusion in sea bream diets: effect on fatty acid composition during ice storage. European Journal of Lipid Science and Technology 112: 985-993.

Castro PL, Caballero MJ, Ginés R, Penedo JC, Montero D, Lastilla MT, et al. (2013) Linseed oil inclusion in sea bream diets: effect on muscle quality and shelf life. Aquaculture Research 46: 75-85.

Coppes Z, Pavlisko A, De Vecchi S (2002) Texture measurements in fish and fish products. Journal of Aquatic Food Product Technology 11: 89-105.

Damez JL, Clerjon S (2008) Meat quality assessment using biophysical methods related to meat structure. Meat Science 80: 132-149.

De Francesco M, Parisi G, Pérez-Sánchez J, Gómez-Réqueni P, Médale F, Kaushik SJ, et al. (2007) Effect of high-level fish meal replacement by plant proteins in gilthead sea bream (Sparus aurata) on growth and body/fillet quality traits. Aquaculture Nutrition 13: 361-372. 
De Haro C, Bueno RPR, Barroso FG, Muros MJS, Cervera MAR, Guil-Guerrero JL (2015) Insect larvae as feed ingredient selectively increase arachidonic acid content in farmed gilthead sea bream (Sparus aurata L.). Aquaculture, doi:10.1111/ are. 12738 .

EFSA (2009) Scientific opinion of the panel on animal health and welfare on a request from the European Commission on welfare aspect of the main systems of stunning and killing of farmed seabass and seabream. The EFSA Journal 1010: 1-52.

EFSA (2010) Scientific Opinion on the substantiation of health claims related to eicosapentaenoic acid (EPA), docosahexaenoic acid (DHA), docosapentaenoic acid (DPA) and maintenance of normal cardiac function (ID 504, 506, 516, 527, $538,703,1128,1317,1324,1325)$, maintenance of normal blood glucose concentrations (ID 566), maintenance of normal blood pressure (ID 506, 516, 703, 1317, 1324), maintenance of normal blood HDL-cholesterol concentrations (ID 506), maintenance of normal (fasting) blood concentrations of triglycerides (ID 506, 527, 538, 1317, 1324, 1325), maintenance of normal blood LDL-cholesterol concentrations (ID $527,538,1317,1325,4689)$, protection of the skin from photo-oxidative (UV-induced) damage (ID 530), improved absorption of EPA and DHA (ID 522, 523), contribution to the normal function of the immune system by decreasing the levels of eicosanoids, arachidonic acid-derived mediators and pro-inflammatory cytokines (ID 520, 2914), and "immunomodulating agent" (4690) pursuant to Article 13(1) of Regulation (EC) No 1924/2006. The EFSA Journal 8: 1796.

European Commission (2007) Council Regulation (EC) No $834 / 2007$ of 28 June 2007 on Organic production and labelling of organic products and repealing Regulation (EEC) No 2092/91. Official Journal of the European Union L 189: $1-23$.

European Commission (2009) Commission Regulation (EC) No 710/2009 of 5 August 2009 amending Regulation (EC) No $889 / 2008$ laying down detailed rules for the implementation of Council Regulation (EC) No 834/2007, as regards laying down detailed rules on organic aquaculture animal and seaweed production. Official Journal of the European Union $L$ 204: 15-34.

European Commission (2012) Facts and Figures on the Common Fisheries Policy - Basic Statistical Data, 2012th edn. Office for Official Publications of the European Union, Luxembourg.

Eurostat (2015) Organic products of aquaculture (from 2013 onwards). Available from URL: http://ec.europa.eu/eurostat/ web/products-datasets/-/org_aqtspec

Fagioli P, Badiani A, Bonaldo A, Testi S, Gatta PP (2009) Freshness quality of gilthead sea bream (Sparus aurata) reared under different farming conditions. Italian Journal of Food Safety 5: 64-69.

FAO (2011) Aquaculture Development. 5. Use of Wild Fish as Feed in Aquaculture. FAO Technical Guidelines for Responsible Fisheries, Rome.

FAO (2014) The State of World Fisheries and Aquaculture 2014. FAO Fisheries and Aquaculture Department, Rome.
Ferreira Pinto J, Nunes ML, Cardoso C (2007) Feeding interruption and quality of cultured gilthead sea bream. Food Chemistry 100: 1504-1510.

Flos R, Reig L, Oca J, Ginovart M (2002) Influence of marketing and different land-based systems on gilthead sea bream (Sparus aurata) quality. Aquaculture International 10: 189-206.

Focardi S, Corsi I, Franchi E (2005) Safety issues and sustainable development of European aquaculture: new tools for environmentally sound aquaculture. Aquaculture International 13: 3-17.

Fountoulaki E, Vasilaki A, Hurtado R, Grigorakis K, Karacostas I, Nengas I, et al. (2009) Fish oil substitution by vegetable oils in commercial diets for gilthead sea bream (Sparus aurata L.); effects on growth performance, flesh quality and fillet fatty acid profile. Recovery of fatty acid profiles by a fish oil finishing diet under fluctuating water temperatures. Aquaculture 289: 317-326.

Ganga R, Montero D, Bell JG, Atalah E, Ganuza E, Vega-Orellana O, et al. (2011) Stress response in sea bream (Sparus aurata) held under crowded conditions and fed diets containing linseed and/or soybean oil. Aquaculture 311: 215-223.

Ghatass Z, Soliman M, Mohamed M (2008) Dielectric technique for quality control of beef meat in the range $10 \mathrm{kHz}-1 \mathrm{MHz}$. American-Eurasian Journal of Scientific Research 3: 62-69.

Ginés R, Palicio M, Zamorano MJ, Argüello A, López JL, Afonso JM (2002) Starvation before slaughtering as a tool to keep freshness attributes in gilthead sea bream (Sparus aurata). Aquaculture International 10: 379-389.

Giuffrida A, Pennisi L, Ziino G, Fortino L, Valvo G, Marino S, et al. (2007) Influence of slaughtering method on some aspects of quality of gilthead seabream and smoked rainbow trout. Veterinary Research Communications 31: 437-446.

Gonçalves A, Mendes R, Nunes ML (2004) Effect of oxygen absorber on the shelf life of gilthead seabream (Sparus aurata). Journal of Aquatic Food Product Technology 13: 49-59.

Grigorakis K (2007) Compositional and organoleptic quality of farmed and wild gilthead sea bream (Sparus aurata) and sea bass (Dicentrarchus labrax) and factors affecting it: a review. Aquaculture 272: 55-75.

Grigorakis K, Alexis MN (2005) Effects of fasting on the meat quality and fat deposition of commercial-size farmed gilthead sea bream (Sparus aurata, L.) fed different dietary regimes. Aquaculture Nutrition 11: 341-344.

Grigorakis K, Fountoulaki E, Giogios I, Alexis MN (2009) Volatile compounds and organoleptic qualities of gilthead sea bream (Sparus aurata) fed commercial diets containing different lipid sources. Aquaculture 290: 116-121.

Haard NF (1992) Control of chemical composition and food quality attributes of cultured fish. Food Research International 25: 289-307.

Hall GM (1997) Fish Processing Technology, 2nd edn. Springer, New York.

Hatlen B, Oaland Ø, Tvenning L, Breck O, Jakobsen JV, Skaret J (2013) Growth performance, feed utilization and product 
quality in slaughter size Atlantic salmon (Salmo salar L.) fed a diet with porcine blood meal, poultry oil and salmon oil. Aquaculture Nutrition 19: 573-584.

Hernández A, García BG, Jordán MJ, Hernández MD (2014a) Improved conservation of gilthead seabream (Sparus aurata) in ice storage. The influence of doses of rosemary extract added to feed. Aquaculture 426-427: 31-40.

Hernández A, García BG, Jordán MJ, Hernández MD (2014b) Study of the dose of thyme essential oil in feed to prolong the shelf life of gilthead seabream (Sparus aurata). Aquaculture Nutrition 21: 740-749.

Hu L, Yun B, Xue M, Wang J, Wu X, Zheng Y, et al. (2013) Effects of fish meal quality and fish meal substitution by animal protein blend on growth performance, flesh quality and liver histology of Japanese seabass (Lateolabrax japonicus). Aquaculture 372-375: 52-61.

Huidobro A, Mendes R, Nunes ML (2001) Slaughtering of gilthead seabream (Sparus aurata) in liquid ice: influence on fish quality. European Food Research and Technology 213: 267-272.

Huidobro A, Pastor A, Tejada M (2006) Quality index method developed for raw gilthead seabream (Sparus aurata). Journal of Food Science 65: 1202-1205.

Hyldig G, Green-Petersen DMB (2004) Quality Index Methodan objective tool for determination of sensory quality. Journal of Aquatic Food Product Technology 13: 71-80.

Iglesias J, Medina I, Bianchi F, Careri M, Mangia A, Musci M (2009) Study of the volatile compounds useful for the characterisation of fresh and frozen-thawed cultured gilthead sea bream fish by solid-phase microextraction gas chromatography-mass spectrometry. Food Chemistry 115: 1473-1478.

Izquierdo MS, Obach A, Arantzamendi L, Montero D, Robaina L, Rosenlund G (2003) Dietary lipid sources for seabream and seabass: growth performance, tissue composition and flesh quality. Aquaculture Nutrition 9: 397-407.

Izquierdo MS, Montero D, Robaina L, Caballero MJ, Rosenlund G, Gines R (2005) Alterations in fillet fatty acid profile and flesh quality in gilthead seabream (Sparus aurata) fed vegetable oils for a long term period. Recovery of fatty acid profiles by fish oil feeding. Aquaculture 250: 431-444.

Jackson A (2012) Fishmeal \& Fish Oil and Its Role in Sustainable Aquaculture, International Aquafeed September October 2012, pp. 18-21. Perendale Publishers Ltd., Cheltenham, UK.

Lawal MO, Aderolu AZ, Aarode OO (2013) Growth and economic performance of Nile Tilapia, Oreochromis niloticus (L.) fingerlings fed diets containing graded levels of sclerotium. AACL Bioflux 6: 180-187.

Lindemann B (1996) Taste reception. Physiological Reviews 76: 719-766.

Marino G, Di Marco P, Petochi T, Finoia MG, Tomassetti P, Porrello S, et al. (2014) Organic vs conventional sea bass and sea bream cage farming. Aquaculture Europe 2014 - Adding Value, October 14-17, San Sebastián, Spain.

Martínez-Llorens S, Vidal AT, Moñino AV, Torres MP, Cerdá MJ (2007) Effects of dietary soybean oil concentration on growth, nutrient utilization and muscle fatty acid composition of gilthead sea bream (Sparus aurata L.). Aquaculture Research 38: 76-81.

Martínez-Llorens S, Vidal AT, Garcia IJ, Torres MP, Cerdá MJ (2009) Optimum dietary soybean meal level for maximizing growth and nutrient utilization of on-growing gilthead sea bream (Sparus aurata). Aquaculture Nutrition 15: 320-328.

Matos E, Gonçalves A, Nunes ML, Dinis MT, Dias J (2010) Effect of harvesting stress and slaughter conditions on selected flesh quality criteria of gilthead seabream (Sparus aurata). Aquaculture 305: 66-72.

Matos E, Silva TS, Tiago T, Aureliano M, Dinis MT, Dias J (2011) Effect of harvesting stress and storage conditions on protein degradation in fillets of farmed gilthead seabream (Sparus aurata): a differential scanning calorimetry study. Food Chemistry 126: 270-276.

Matos E, Gonçalves A, Bandarra N, Colen R, Nunes ML, Valente LMP, et al. (2012) Plant proteins and vegetable oil do not have detrimental effects on post-mortem muscle instrumental texture, sensory properties and nutritional value of gilthead seabream. Aquaculture 358-359: 205-212.

Matos E, Silva TS, Wulff T, Valente LMP, Sousa V, Sampaio E, et al. (2013) Influence of supplemental maslinic acid (olivederived triterpene) on the post-mortem muscle properties and quality traits of gilthead seabream. Aquaculture 396-399: 146-155.

Matos E, Silva TS, Colen R, Dinis MT, Dias J (2014) Plant protein and vegetable oil-based diets modulate gilthead seabream (Sparus aurata) muscle biochemical status and proteolytic enzymes at an early postmortem stage. Aquaculture Nutrition 20: $153-162$.

Meloni G (2010) Chemical Composition of the Muscle of Wild, Extensively and Intensively-Reared Gilthead Seabream (Sparus aurata Linnaeus, 1758) from Sardinia, Indirizzo Scienze e Tecnologie Zootecniche, pp. 149. Università degli Studi di Sassari, Sassari.

Mennella JA, Pepino MY, Reed DR (2005) Genetic and environmental determinants of bitter perception and sweet preferences. Pediatrics 115: e216-e222.

Menoyo D, Izquierdo MS, Robaina L, Gines R, Lopez-Bote CJ, Bautista JM (2004) Adaptation of lipid metabolism, tissue composition and flesh quality in gilthead sea bream (Sparus aurata) to the replacement of dietary fish oil by linseed and soyabean oils. British Journal of Nutrition 92: $41-52$.

Mente E, Karalazos V, Karapanagiotidis IT, Pita C (2011) Nutrition in organic aquaculture: an inquiry and a discourse. Aquaculture Nutrition 17: e798-e817.

Mente E, Stratakos A, Boziaris I, Kormas KA, Karalazos V, Karapanagiotidis IT, et al. (2012) The effect of organic and conventional production methods on sea bream growth, health and body composition: a field experiment. Scientia Marina 76: 549-560.

Mochizuki Y (2001) Texture Profile Analysis. In: Wrolstad RE (ed.) Current Protocols in Food Analytical Chemistry, pp. H2.3. John Wiley \& Sons, New Jersey. 
Montero D, Mathlouthi F, Tort L, Afonso JM, Torrecillas S, Fernández-Vaquero A, et al. (2010) Replacement of dietary fish oil by vegetable oils affects humoral immunity and expression of pro-inflammatory cytokines genes in gilthead sea bream Sparus aurata. Fish \& Shellfish Immunology 29: 1073-1081.

Morales JC (1991) Acuicultura Marina Animal. Ediciones Mundi-Prensa, Madrid.

Moretti V, Turchini G, Bellagamba F, Caprino F (2003) Traceability issues in fishery and aquaculture products. Veterinary Research Communications 27: 497-505.

Nácher-Mestre J, Serrano R, Benedito-Palos L, Navarro JC, López FJ, Pérez-Sánchez J (2009) Effects of fish oil replacement and re-feeding on the bioaccumulation of organochlorine compounds in gilthead sea bream (Sparus aurata L.) of market size. Chemosphere 76: 811-817.

Nácher-Mestre J, Serrano R, Benedito-Palos L, Navarro J, López F, Kaushik S, et al. (2010) Bioaccumulation of polycyclic aromatic hydrocarbons in gilthead sea bream (Sparus aurata L.) exposed to long term feeding trials with different experimental diets. Archives of Environmental Contamination and Toxicology 59: 137-146.

Nasopoulou C, Stamatakis G, Demopoulos CA, Zabetakis I (2011) Effects of olive pomace and olive pomace oil on growth performance, fatty acid composition and cardio protective properties of gilthead sea bream (Sparus aurata) and sea bass (Dicentrarchus labrax). Food Chemistry 129: $1108-1113$.

Naylor RL, Goldburg RJ, Primavera JH, Kautsky N, Beveridge MCM, Clay J, et al. (2000) Effect of aquaculture on world fish supplies. Nature 405: 1017-1024.

Nengas I, Alexis MN, Davies SJ (1999) High inclusion levels of poultry meals and related byproducts in diets for gilthead seabream Sparus aurata L. Aquaculture 179: 13-23.

Nilsen H, Esaiassen M, Heia K, Sigernes F (2002) Visible/nearinfrared spectroscopy: a new tool for the evaluation of fish freshness? Journal of Food Science 67: 1821-1826.

Nogueira N, Cordeiro N, Andrade C, Aires T (2012) Inclusion of low levels of blood and feathermeal in practical diets for gilthead seabream (Sparus aurata). Turkish Journal of Fisheries and Aquatic Sciences 12: 641-651.

Ólafsdóttir G, Kristbergsson K (2006) Electronic-nose technology: application for quality evaluation in the fish industry. In: Nicolay X (ed) Odors in the Food Industry, pp. 57-74. Springer, New York.

Ólafsdóttir G, Nesvadba P, Di Natale C, Careche M, Oehlenschläger J, Tryggvadóttir SV, et al. (2004) Multisensor for fish quality determination. Trends in Food Science \& Technology 15: 86-93.

Orban E, Sinesio F, Paoletti F (1997) The functional properties of the proteins, texture and the sensory characteristics of frozen sea bream fillets (Sparus aurata) from different farming systems. LWT - Food Science and Technology 30: 214-217.

Ortuño J, Esteban MA, Meseguer J (2001) Effects of short-term crowding stress on the gilthead seabream (Sparus aurata L.) innate immune response. Fish \& Shellfish Immunology 11: 187-197.

Pérez JA, Rodríguez C, Bolaños A, Cejas JR, Lorenzo A (2014) Beef tallow as an alternative to fish oil in diets for gilthead sea bream (Sparus aurata) juveniles: effects on fish performance, tissue fatty acid composition, health and flesh nutritional value. European Journal of Lipid Science and Technology 116: 571-583.

Picard B, Lefevre F, Lebret B (2012) Meat and fish flesh quality improvement with proteomic applications. Animal Frontiers 2: $18-25$.

Piccino M, Schiavone R, Zilli L, Sicuro B, Storelli C, Vilella S (2013) Sea cucumber meal as alternative protein source to fishmeal in gilthead sea bream (Sparus aurata) nutrition: effects on growth and welfare. Turkish Journal of Fisheries and Aquatic Sciences 13: 305-313.

Poli BM (2009) Farmed fish welfare-suffering assessment and impact on product quality. Italian Journal of Animal Science $\mathbf{8}$ : 137-160.

Poli BM, Parisi G, Scappini F, Zampacavallo G (2005) Fish welfare and quality as affected by pre-slaughter and slaughter management. Aquaculture International 13: 29-49.

Prein M, Bergleiter S, Ballauf M, Brister D, Halwart M, Hongrat $\mathrm{K}$, et al. (2012) Organic aquaculture: the future of expanding niche markets. In: Subasinghe RP, Arthur JR, Bartley DM, De Silva SS, Halwart M, Hishamunda N, et al. (eds) Farming the Waters for People and Food, pp. 549-567. FAO, Rome and NACA, Bangkok.

Ramalho Ribeiro A, Gonçalves A, Colen R, Nunes ML, Dinis MT, Dias J (2015) Dietary macroalgae is a natural and effective tool to fortify gilthead seabream fillets with iodine: effects on growth, sensory quality and nutritional value. Aquaculture 437: 51-59.

Ramalho-Ribeiro A, Colen R, Dias J, Dinis MT, Gonçalves A, Bandarra N, et al. (2013) Animal-processed ingredients in gilthead seabream feeds. Aquaculture Europe 2013 - Making Sense of Science, August 9-12, Trondheim, Norway.

Reilly A, Käferstein F (1997) Food safety hazards and the application of the principles of the hazard analysis and critical control point (HACCP) system for their control in aquaculture production. Aquaculture Research 28: 735-752.

Richard M, Cardinal M, Fabre R, Maurice JT, Cornet J, DonnayMoreno C, et al. (2010) SEACASE Project: Improving the fish quality of an intensive system by a short crossing in algae ponds, International Workshop on Sustainable Extensive and SemiIntensive Aquaculture Production in Southern Europe, January 20-21. Tavira, Portugal.

Roncarati A, Melotti P, Dees A, Mordenti O, Angellotti L (2006) Welfare status of cultured seabass (Dicentrarchus labrax L.) and seabream (Sparus aurata L.) assessed by blood parameters and tissue characteristics. Journal of Applied Ichthyology 22: 225-234.

Sánchez-Lozano NB, Martínez-Llorens S, Tomás-Vidal A, Cerdá MJ (2009) Effect of high-level fish meal replacement by pea and rice concentrate protein on growth, nutrient utilization 
and fillet quality in gilthead seabream (Sparus aurata, L.). Aquaculture 298: 83-89.

Semenov S (2009) Microwave tomography: review of the progress towards clinical applications. Philosophical Transactions of the Royal Society A: Mathematical, Physical and Engineering Sciences 367: 3021-3042.

Sigholt T, Erikson U, Rustad T, Johansen S, Nordtvedt T, Seland A (2006) Handling stress and storage temperature affect meat quality of farmed-raised Atlantic salmon (Salmo salar). Journal of Food Science 62: 898-905.

Silva TS, Cordeiro OD, Matos ED, Wulff T, Dias JP, Jessen F, et al. (2012a) Effects of preslaughter stress levels on the postmortem sarcoplasmic proteomic profile of gilthead seabream muscle. Journal of Agricultural and Food Chemistry 60: 94439453.

Silva TS, Matos E, Cordeiro OD, Colen R, Wulff T, Sampaio E, et al. (2012b) Dietary tools to modulate glycogen storage in gilthead seabream muscle: glycerol supplementation. Journal of Agricultural and Food Chemistry 60: 10613-10624.

Tejada M, Huidobro A (2002) Quality of farmed gilthead seabream (Sparus aurata) during ice storage related to the slaughter method and gutting. European Food Research and Technology 215: 1-7.

Terova G, Addis MF, Preziosa E, Pisanu S, Pagnozzi D, Biosa G, et al. (2011) Effects of postmortem storage temperature on sea bass (Dicentrarchus labrax) muscle protein degradation: analysis by 2-D DIGE and MS. Proteomics 11: 2901-2910.

Trocino A, Xiccato G, Majolini D, Tazzoli M, Bertotto D, Pascoli F, et al. (2012) Assessing the quality of organic and conventionally-farmed European sea bass (Dicentrarchus labrax). Food Chemistry 131: 427-433.

Trushenski J, Rosenquist J, Gause B (2011) Growth performance, tissue fatty acid composition, and consumer appeal of rainbow trout reared on feeds containing terrestrially derived rendered fats. North American Journal of Aquaculture 73: 468-478.

Turchini GM, Torstensen BE, Ng W-K (2009) Fish oil replacement in finfish nutrition. Reviews in Aquaculture 1: 10-57.

Urbieta F, Ginés R (2000) Optimisation of slaughtering method in gilthead sea bream (Sparus aurata). Industrial application in fish farms. Cahiers Options Méditerranéennes 51: 71-77.

Valente LMP, Cornet J, Donnay-Moreno C, Gouygou JP, Bergé JP, Bacelar M, et al. (2011) Quality differences of gilthead sea bream from distinct production systems in Southern Europe: intensive, integrated, semi-intensive or extensive systems. Food Control 22: 708-717.

Verbeke W, Sioen I, Pieniak Z, Van Camp J, De Henauw S (2005) Consumer perception versus scientific evidence about health benefits and safety risks from fish consumption. Public Health Nutrition 8: 422-429.

Vizcaíno AJ, López G, Saéz MI, Jiménez JA, Barros A, Hidalgo L, et al. (2014) Effects of the microalga Scenedesmus almeriensis as fishmeal alternative in diets for gilthead sea bream, Sparus aurata, juveniles. Aquaculture 431: 34-43.

Volpato GL, Gonçalves-de-Freitas E, Fernandes-de-Castilho M (2007) Insights into the concept of fish welfare. Diseases of Aquatic Organisms 75: 165-171.

Wassef E, Saleh N, El-Abd El-Hady H (2009) Vegetable oil blend as alternative lipid resources in diets for gilthead seabream, Sparus aurata. Aquaculture International 17: 421-435.

Xuan X, Wen X, Li S, Zhu D, Li Y (2013) Potential use of macro-algae Gracilaria lemaneiformis in diets for the black sea bream, Acanthopagrus schlegelii, juvenile. Aquaculture 412413: 167-172.

Zhang HZ, Lee TC (1997) Rapid near-infrared spectroscopic method for the determination of free fatty acid in fish and its application in fish quality assessment. Journal of Agricultural and Food Chemistry 45: 3515-3521. 